\title{
Tumour growth and immune evasion as targets for a new strategy in advanced cancer
}

\author{
Andrea Nicolini1,*, Paola Ferrari', Giuseppe Rossi2,+ and Angelo Carpi ${ }^{3, *}$ \\ 'Department of Oncology, Transplantations and New Technologies in Medicine, University of Pisa, Pisa, Italy \\ zUnit of Epidemiology and Biostatistics, Institute of Clinical Physiology, National Council of Research, Pisa, Italy \\ ${ }^{3}$ Department of Clinical and Experimental Medicine, University of Pisa, Pisa, Italy \\ Correspondence should be addressed to A Nicolini: andrea.nicolini@med.unipi.it \\ *(A Nicolini and A Carpi are now retired) \\ ${ }^{\dagger}$ (G Rossi is now deceased)
}

\begin{abstract}
It has become clearer that advanced cancer, especially advanced breast cancer, is an entirely displayed pathological system that is much more complex than previously considered. However, the direct relationship between tumour growth and immune evasion can represent a general rule governing the pathological cancer system from the initial cancer cells to when the system is entirely displayed. Accordingly, a refined pathobiological model and a novel therapeutic strategy are proposed. The novel therapeutic strategy is based on therapeutically induced conditions (undetectable tumour burden and/or a prolonged tumour 'resting state'), which enable an efficacious immune response in advanced breast and other types of solid cancers.
\end{abstract}

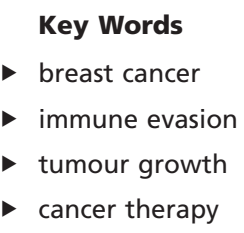

Endocrine-Related Cancer (2018) 25, R577-R604

\section{Introduction}

As testified by ancient writers, human beings have always been suffering from cancer. It is likely that environmental pollution and prolonged ageing concomitant with some radical lifestyle changes (Ferlay et al. 2012, Howell et al. 2014) are among the main reasons for the increasing prevalence of cancer in the modern era. In its advanced stages, cancer is often an incurable disease and represents a serious threat to human life. In 2012, the International Agency for Research on Cancer reported 14.1 million new cancer diagnoses, 8.2 million cancer deaths and 32.6 million cancer diagnoses of $<5$ years worldwide. The cancer death rate ranges 69-173 per 100,000 men and 65-119 per 100,000 women (Ferlay et al. 2012). Thus, cancer has now acquired a major social relevance. Among women, breast cancer is the most common cancer in most regions of the world, with an estimated incidence of 246,000 new cases (29\% of all cancer cases) and
40,450 deaths ( $14 \%$ of all cases) in 2016 in the United States (Siegel et al. 2016). This paper reviews some recent experimental and clinical data to propose an innovative therapeutic strategy for advanced breast and other cancers based on the relationship between tumour growth and immune evasion.

\section{The biological cancer hallmarks and the current model}

In 2011, Hanahan and Weinberg published an update (Hanahan \& Weinberg 2011) of their milestone article on the principal hallmarks of cancer (Hanahan \& Weinberg 2000). The authors reported that the principal biological capabilities acquired by cancer cells are sustaining proliferative signalling, evading growth suppressors, resisting cell death, enabling replicative 
immortality, inducing angiogenesis, activating invasion and metastasis, reprogramming energy and metabolism and evading immune destruction. In this updated model, genomic instability and inflammation are the basis of all the hallmarks. The network sustaining cancer growth and progression is represented as an overall integrated circuitry comprising a few interconnected subcircuits. In turn, each subcircuit comprises multiple interconnected pathological molecular pathways fostering different hallmark capabilities. Here, we focus on advances in the role of tumour growth and immune evasion in tumour progression and diffusion.

\section{Tumour growth}

\section{Sustaining proliferative signalling}

The growth-promoting signals in cancer cells are mainly induced by growth factors that bind cell surface receptors with intracellular tyrosine kinase domains. In addition, growth factors acquire the capability to carry mitogenic signals in some different ways. In particular, autocrine or paracrine proliferative stimulations and downstream molecular pathways, either constitutively activated or activated following somatic mutations, are common (Davies \& Samuels 2010, Nicolini et al. 2015). Many other mechanisms of tumour growth promotion (Aziz et al. 2015, Gao et al. 2015a, Rohatgi et al. 2015, SPN et al. 2015, Wang et al. 2015a) have been reported. Some of these studies (Song et al. 2015, Wang et al. 2015c, Koval et al. 2016, van Geldermalsen et al. 2016) included triplenegative cancer subtype.

\section{Evading growth suppressors}

In recent years, a few tumour suppressor genes and the inhibition of anti-proliferative mechanisms have been identified (Kochupurakkal et al. 2015, Ma et al. 2015). The constitutive activation of the interferon gamma $($ IFN $\gamma)$ /signal transducers and activators of transcription (STAT) 1/interferon-regulatory factor (IRF)-1 axis (T-helper (Th) 1 phenotype) correlates with good prognosis and predicts better response to anti-cancer therapy (Ascierto et al. 2011). IRF-1 regulates the transcription of a set of target genes that play principal roles in tumour immune surveillance and immune system development. The mechanisms by which IRF-1 mediates tumour suppression are not clear; however, several IRF-1 target genes that inhibit growth by cell cycle arrest and promote apoptosis have been identified (Dou et al. 2014). Many reports have suggested a relevant role of IFN $\gamma /$ STAT1/IRF-1 axis in the endocrine resistance of oestrogen receptor (ER)positive breast cancer cells (Clarke et al. 2009, Ning et al. 2010, Schwartz et al. 2011, Schwartz-Roberts et al. 2015). Yang et al. (2017) recently showed that the suppression of the immune functions of $\mathrm{T}$ cells in the tumour microenvironment (TME) is another mechanism by which oestrogen drives cancer progression. Accordingly, in two experimental studies, IRF-1- and IFN $\gamma$-mediated apoptosis was induced by the anti-oestrogens tamoxifen (Bowie et al. 2004) and fulvestrant (Bouker et al. 2014). These observations also suggest changes in gene expression from heterogeneous tumour samples. In breast cancer, additional mechanisms regarding the evasion of tumour growth suppressors (Hu \& Xie 2015, Xu et al. 2015, You et al. 2016) have been described.

\section{Resisting cell death}

In principle, cell death, mainly by apoptosis or necrosis, is thought to be a main natural hindrance to cancer development. Apoptosis plays a fundamental role in the homeostasis of healthy tissues. In the last decades, it has been fully elucidated how apoptosis is triggered in response to different physiological stimuli. The apoptotic machinery is governed by upstream regulators and downstream effectors, and the regulators include two major circuits: the extrinsic and intrinsic apoptotic programmes (Cory \& Adams 2002, Kiraz 2016). Recently, several mechanisms that can affect apoptosis in breast cancer cells have been described (Sayeed et al. 2013, Armstrong et al. 2015, Farrugia et al. 2015, Gao et al. 2015b, Han et al. 2015, Li et al. 2015, Liu et al. 2015, Saqcena et al. 2015, Zhou et al. 2015, Cao et al. 2016, Shrestha et al . 2016).

\section{Enabling replicative immortality}

Other investigational findings on senescence (El Hasana et al. 2015) and autophagy (Artero-Castro et al. 2015) have been reported. Autophagy is a 'self-eating' process initiated by cancer cells in response to various stresses. Both autophagy upregulation and downregulation have been found in cancer, suggesting its dual oncogenic and tumour-suppressing roles during malignant transformation (Marinković et al. 2018). However, in the last decades, accumulating evidence by experimental studies has indicated the relevance of autophagy in cancer progression and diffusion. These studies have elucidated further mechanisms of autophagy in human ER- $\alpha+$ (Galindo-Moreno et al. 2017, Hou et al. 2017, Leignadier et al. 2017, Wang et al. 2017) or ER- $\alpha+$ and ER- $\alpha-$ 
(Han et al. 2017a, Lin et al. 2017, Zhou et al. 2017a,c) breast cancer cells. In addition, they found that cytotoxic (chemo or endocrine) treatment (Kondo et al. 2005, Chen et al. 2011) and severe hypoxia (Rouschop 2010) are two major stresses that could be evaded by autophagy. In fact, in both cases, autophagy allows the cancer cell to survive and become refractory to chemo-endocrine therapy and chemoradiotherapy. Other translational research studies (Ueno et al. 2016, Han et al. 2017b, Tavera-Mendoza et al. 2017, Zhou et al. 2017b) have been conducted to identify novel prognostic biomarkers or key targets for developing new therapeutic agents. Some clinical trials using the autophagy inhibitors chloroquine (CQ) or hydroxychloroquine (HCQ) are ongoing. Two of them (NCT02333890 and NCT01023477) are evaluating CQ efficacy in decreasing tumour growth prior to surgical intervention, and one (NCT01446016) is evaluating CQ efficacy when given in combination with taxane in metastatic setting in patients who had previously failed to respond to anthracycline chemotherapy. In two trials (NCT03032406 and NCT03400254), HCQ alone or with everolimus or gedatolisib has been administered for preventing recurrent breast cancer. In another trial (NCT00765765), HCQ has been administered in a metastatic setting in combination with ixabepilone vs ixabepilone alone, with the decrease in tumour growth and response rate being evaluated as the main end points. All these trials have recruited breast cancer patients independent of hormone receptor status. A further ongoing trial enrolling ER+ patients (NCT02414776) is evaluating the response rate following the addition of HCQ in patients showing progress with hormonal therapy.

\section{Immune evasion}

\section{Mechanisms of immune suppression or immune escape}

Indeed, it is now a consolidated concept that during tumour development, a chronic inflammatory microenvironment reduces the anti-tumoural immune response and favours the escape of tumour from immune elimination (Clevers 2004, Bui \& Schreiber 2007). Inflammatory immune cells include tumour-associated macrophages (TAMs), cytotoxic T (CD8) lymphocytes (CTLs), Th (CD4) lymphocytes, natural killer (NK) cells, regulatory $\mathrm{T}$ (Treg) cells and myeloid-derived suppressor cells (MDSCs). Among them, Treg cells, MDSCs and macrophages are mainly involved in the immunosuppressive action (Vasaturo et al. 2015) via the secretion of key molecules, such as transforming growth factor beta (TGF- $\beta$ ), prostaglandin E2, indoleamine 2,3-dioxygenase and interleukin (IL)-10 (Capietto et al. 2011). The abundance of Tregs, MDSCs and TAMs in the stroma also helps cancercells to escapeimmune surveillance and is associated with worse prognosis (Mantovani et al. 2006, Greten et al. 2011, Bergenfelz et al. 2015, Li et al. 2018), whereas CTLs are associated with a good prognosis (Tosolini et al. 2011). Signals derived from cancer cells and the stroma determine the TAM phenotype from M1, which stimulates immunoprotective inflammatory responses, and M2, which has an immunosuppressive action. M2 phenotype is found in most tumours where the TAMs induce angiogenesis, tumour growth and metastasis by secreting soluble mediators, cytokines and chemokines and by directly interacting with cancer stem cells (CSCs) (Hao et al. 2012). Soluble mediators, mainly growth factors, cytokines and chemokines, in addition to host immune cells are also produced by cancer-associated fibroblasts (CAFs) or by tumour cells themselves. Several growth factors, namely TGF- $\beta$, insulin-like growth factor 2 (IGF-2) and vascular endothelial growth factor (VEGF), cytokines, namely IL-1, IL-4, IL-6, IL-8, IL-10 and tumournecrosis factor alpha, chemokines, namely chemokine (C-X-C motif) ligand 1 and $\mathrm{C}-\mathrm{C}$ motif chemokine receptor 7, have been reported to be closely involved in tumour progression, invasion and immune escape (Eftekhari et al. 2017, Gál et al. 2017, Setrerrahmane \& Xu 2017) and are potential targets for anti-tumour therapies. Moreover, cancer cells not only express these soluble mediators but also frequently overexpress the related receptors to escape from the immune responses (Setrerrahmane \& Xu 2017). As is well known, tumour antigens must be presented in a human leucocyte antigen (HLA)-restricted way to be recognized by T-cell receptors. Impaired HLA-I or HLA-II expression prevent the activation of cytotoxic immune cells or affect the antigen-presenting capability of antigenpresenting cells. In addition, aberrant HLA-G expression by cancer cells inhibit the activity of all immune cells. These HLA-associated immune evasion mechanisms occur early and frequently in most cancer types (McGranahan et al. 2017, Rodríguez 2017). Nod-like receptor family caspase recruitment domain-containing 5 (NLRC5) has been found to be a crucial transcriptional co-activator of major histocompatibility complex (MHC) class I gene expression. NLRC5 expression strongly correlates with genes in the MHC class I antigen presentation pathway, including transporter associated with antigen processing (TAP) 1. In different types of cancer, epigenetic and genetic alterations are most prevalent in NLRC5 among all the MHC class I-related genes and are associated with impaired expression of the MHC I pathway components 
and immune evasion (Yoshihama et al. 2016). Accordingly, TAP1 downregulation has been shown to elicit immune escape in colorectal cancer (Ling et al. 2017). Further described mechanisms of immune evasion in breast and other cancer cells involve increased programmed deathligand 1 (PD-L1) expression (Coelho et al. 2017, Martinez et al. 2017), stabilized PD-L1 mRNA (Glodde \& Hölzel 2017) and altered PD-L1 function (Maj et al. 2017) by different molecular pathways. Nuclear factor (NF)-kb and increased PD-L1 expression are involved in immune evasion and the progression of triple-negative breast cancer (TNBC) (Maeda et al. 2018). The expression of the enzyme arginase 1 (ARG 1) as a key mediator of immune suppression (Steggerda et al. 2017) and the loss-of-function Janus-activated kinase (JAK) 1 mutations suggestive of immune suppression (Albacker et al. 2017) have also been reported in multiple cancer types. Moreover, other recent studies have reported on immune evasion (Hix et al. 2011, Khaled et al. 2013, Markosyan et al. 2013, Loumagne et al. 2014, Tao et al. 2014, Virtanen et al. 2014, Olesch et al. 2015, Zhang et al. 2015b,c, Zelenay et al. 2015, Gameiro et al. 2016, Heng et al. 2016, Lim et al. 2016, Loi et al. 2016).

\section{Probable reasons for the discrepancy between genetic and biological advances and clinical outcome}

Despite the vast acquired biological knowledge, advanced breast cancer remains a disease with poor prognosis. Currently, endocrine therapy, chemotherapy and, more recently, the so-called 'targeted therapies' are common medical treatments for the advanced disease stages. Despite the availability of new biological drugs and a more rational use of therapies, the clinical outcome remains poor. Thus, the life expectancy of patients with advanced disease is dismal, and the median survival of a mixed population of metastatic breast cancer patients has not substantially improved in the last decades (Chia et al. 2007, Dawood et al. 2008, Cheng et al. 2009, Welt et al. 2016, Cardoso et al. 2017, Toss et al. 2017).

\section{The genetic and epigenetic heterogeneities}

To date, cDNA and mRNA sequencing has allowed several 'genetic signatures' and molecular profiles to be defined, which usually differ in different tumours and different samples of the same tumour (spatial intratumour heterogeneity) (Yachida et al. 2010, Verigos \& Magklara 2015). Each of these multigene sets is different in terms of the number and, at least in part, the genes involved. Moreover, although the most relevant genes for predicting patient outcome are those involved in cell proliferation, only Oncotype DX (Paik et al. 2004) and Mammaprint (van de Vijver et al. 2002) can be routinely recommended for predicting response to a specific type of therapy (Duffy et al. 2017). cDNA heterogeneity is increased further by epigenetic alterations and their ability to regulate gene expression (silencing oncogenes or activating repressor genes). The relevance of the contribution of epigenetic alterations to the genetic cancer heterogeneity became clear when hypo/hypermethylation of DNA and micro RNA (miRNA) function were investigated. Many patterns of methylation changes (hypo or hyper) have been described to be associated with different canonical pathways (Rodenhiser et al. 2008) or sometimes corresponding to different known genetic signatures. Many upregulated or downregulated miRNAs, numerous oncogenic and tumour-suppressive miRNAs involved in relevant molecular pathways, such as proliferation and survival, cell migration and metastasis, CSC phenotypes and epithelial-to-mesenchymal transition (EMT) processes, have been reported (Bertoli et al. 2015, Wang et al. 2015b). Currently, breast cancer classification into molecular subtypes considers the genetic characteristics of tumour. If the epigenetic alterations were also taken into account, many more subtypes could be generated. This inconsistency indicates the existence of further different molecular subtypes of breast cancer and even more complex classifications than are currently known.

\section{The genomic instability and the plasticity of phenotypes}

Genomic instability is a prominent property of cancer cells that allows them to accumulate random mutations over time to acquire and better orchestrate their hallmark capabilities. The accumulation of mutations occurs due to the naturally developing genetic aberrations combined with those following the selective pressure of anti-cancer treatments (Zardavas et al. 2015). Tumour stroma is also involved in genomic instability. In a study of 51 breast cancer gene (BRCA)1/2-related cancers and 134 sporadic breast cancers, the accumulation of genomic instability in the tumour stroma corresponded to that in the neoplastic epithelium (Weber et al. 2006). In another study, human orthologs of genes identified in the stromal reaction to tumour progression in a mouse model were also expressed in several human cancers (Bacac et al. 2006). These and other findings indicated that genomic instability induces 
stromal alterations capable of promoting neoplastic transformation and stimulating tumour progression. In addition, genomic instability is favoured by the compromised surveillance system that normally detects and resolves defects in DNA or forces genetically damaged cells into senescence or apoptosis (Kastan 2008, Jackson \& Bartek 2009). Recently, genetic differences have been shown between a primary breast tumour and its associated metastatic lesions, which developed over time (Zardavas et al. 2015). Moreover, sequencing data from cell populations as well as from single cells have shown three classes of mutations, namely (a) clonal mutations observed in the population sample and in most single tumour cells, (b) subclonal mutations found only in single cells and not in the population and (c) de novo mutations observed in one tumour cell only (Wang et al. 2014). These findings indicate that there is significant tumour heterogeneity, even at the single-cell level and suggest that different tumour subclones are the result of the accumulation of different point mutations over time (Wang et al. 2014, Wang \& Navin 2015). Thus, genomic instability of stroma and cancer cells accounts mainly for temporal intratumour heterogeneity and describes tumour evolution. Biological plasticity is another important feature that significantly contributes to temporal tumour heterogeneity during cancer progression. Therefore, an initially more genetically homogeneous population of cells within a tumour becomes phenotypically heterogeneous due to the presence of cells in distinct states of differentiation following phenotypic variability, at least in part. The main example of this biological plasticity is the phenotypic variability implicit in CSCs where the activation of an EMT (Kalluri \& Weinberg 2009) or endothelial-to-mesenchymal transition (Potenta et al. 2008, Mihira et al. 2012) programme converts epithelial or resident fibroblasts or endothelial cancer cells into mammary cancer cells (MCCs) or CAFs. On the other hand, programmes that convert endothelial cells to mesenchymal cells or mesenchymal cells to endothelial cells have been documented within stroma (Medici et al. 2010). Although all of these programmes and the contextual signals tend to promote an invasive tumour phenotype, in the absence of exposure to these signals, cancer cells may also revert to a non-invasive state through a process termed mesenchymal-epithelial transition (MET). This process is associated with cancer progression and metastasis. At the site of metastases, mesenchymal tumour cells must undergo MET as metastases recapitulate the pathology of the corresponding primary tumours. Thus, 'the cellular plasticity, the ability to undergo EMT and, subsequently,
MET in the appropriate microenvironment, is a key feature of a successful metastatic cell' (Hugo et al. 2007). Moreover, cells do not complete these transformation programmes and frequently acquire a few traits of the new phenotype while continuing to express residual traits of the old phenotype. This contributes to increased temporal tumour heterogeneity.

\section{Incomplete knowledge of the mechanisms and the 'contextual signalling' that affect pathological molecular pathways sustaining the cancer hallmarks}

The deficiencies in the knowledge and the complexity of the mechanisms sustaining tumour growth are well known to the investigators and are also clearly mentioned in the updated article by Hanahan \& Weinberg (2011). In a recent review (Smithson et al. 2016), it has been suggested that 'signalling represents the language of the cell, where molecules (words) and cellular context (syntax) serve as units of informational content'; in addition, the authors stated that 'when we study signalling pathways in normal cells or in the setting of cancer, we often fail to consider how the cellular language conferred by these pathways is influenced by context, that is, the different extracellular signals present in the immediate milieu, the various adaptive responses that limit and promote intracellular signal transduction, the innate properties of distinct cell types responding to these cues, and the impact of epigenetic/genomic changes on the ultimate consequence of these informational signals'. They concluded that 'a deeper appreciation of contextual signalling may improve our understanding of the basic principles that govern development'. Recently, other authors have stated that 'a direct approach of inhibiting single oncogenic proteins misses the dynamic network context governing the network signal processing' (Fey et al. 2016). Overall, these deductions demonstrate that the comprehension of cancer is a work in progress.

\section{Chemo, hormone and targeted therapies: main limitations}

Locally confined primary cancer is commonly called 'early' or 'advanced cancer' according to whether, at the time of diagnosis, it corresponds to the initial or successive stages of the ongoing internationally recognized clinicopathological classifications. Regional involvement (regional lymph nodes or regions around the primary cancer) makes any locally confined primary cancer an advanced cancer. When organs that are distant 
from the site of primary cancer are involved, cancer is called metastatic, and even metastatic disease constitutes advanced cancer. Although surgery and radiotherapy function loco-regionally, conventional chemo, hormone and targeted therapies are directed to cancer cells wherever they are present in the body tissues. Therefore, they are usually administered to patients with advanced cancer to prevent (adjuvant therapy) or treat (salvage therapy) metastatic disease. However, the development of acquired resistance and toxicity are two limiting aspects common to all therapies, although they generally differ according to the type of drug. In hormone-sensitive patients, hormone therapy is very rarely interrupted by heavy toxicity (Nicolini et al. 2016). It is likely that the absent or mild side effects and a more prolonged efficacy reflect the limited number of normal tissues involved in addition to cancer cells (Couse \& Korach 1999) as well as the more terminal inhibition of multiple transduction signalling pathways activating the targeted intracellular biological processes respectively. Usually, because of the lack of significant efficacy when administered alone, the targeted therapies are given in combination with chemotherapy or hormone therapy. Nevertheless, patients receiving targeted therapies often exhibit moderate or heavy toxicity likely attributable, as for chemotherapy, to the unselected target cells. In these patients, the mean short duration of the efficacy likely reflects the higher number of mechanisms potentially responsible for the development of resistance (Roskoski 2014, Fey et al. 2016, Granata et al. 2016). Recently, a plethora of these mechanisms of resistance has been investigated in melanoma skin cancer (Wellbrok \& Arozarena 2016). Table 1 summarizes the principal probable reasons of the discrepancy between the advances in biological knowledge and the persistently poor outcomes of advanced breast cancer.

\section{Advanced breast cancer: prognostic relevance of tumour growth and immune evasion}

In advanced breast cancer, the 'driver genes' or recurring 'significantly mutated genes' involved in the 'genetic signatures' that are specific for the molecular subtypes are known, in addition to some principal pathways and molecular cascades that they activate or inhibit (Cancer Genome Atlas Network 2012, Stephens et al. 2012). However, it appears that a lot of information regarding the regulation and posttranslational modifications of the altered genes, the multiple signalling cascades they activate, their positive and negative loops and their interconnections is still unknown (Le Romancer et al. 2011). In addition, the way in which a single molecular pathway and subcircuit contribute to the final hallmarks is unknown. The complexity of the system suggests that the overall integrated network on which each tumour is based is by far unknown, thereby facilitating the development of resistance to any conventional therapy. Thus, the complexity of the pathobiological model of advanced cancer, which has been uncovering following the progress in genetics and molecular biology, can be compared to the knowledge of the universe following the Hubble advent. This complexity accounts for the relatively poor clinical outcome. In fact, not temporally planned, not appropriately directed and/or not appropriately synergized targeting of one or a few molecular signalling pathways is unlikely to affect the outcome of such complex and

Table 1 Probable main reasons of the discrepancy between the biological advances in knowledge and persistent relatively poor outcome of advanced breast cancer from therapies.

\begin{tabular}{|c|c|}
\hline System & Problem \\
\hline Tumour & $\begin{array}{l}\text { Spatial heterogeneity: Many genetic and } \\
\text { epigenetic alterations that differ within the same } \\
\text { tumour and from one to another. The } \\
\text { contribution of the epigenetic alterations is } \\
\text { unexpectedly relevant }\end{array}$ \\
\hline & $\begin{array}{l}\text { Temporal heterogeneity: Genomic instability and } \\
\text { biologic plasticity are relevant properties of } \\
\text { cancer cells }\end{array}$ \\
\hline Microenvironment & $\begin{array}{l}\text { The stroma contribution: The cross-talk between } \\
\text { stroma and cancer cells }\end{array}$ \\
\hline
\end{tabular}

The 'contextual signalling': different extracellular signals present in the immediate milieu Conventional therapies Time-limited efficacy

Result
Any tumour has the own
'genetic signature' that
differs from any other

Any tumour can change its phenotype during progression

Further increase in the complexity of the overall network of the molecular pathways

Different adaptive responses of cancer cells

Toxicity, early arising of resistance
References

Yachida et al. (2010), Verigos \& Magklara (2015)

Wang et al. (2014)

Nicolini \& Carpi (2009), Hanahan \& Weinberg (2011)

Smithson et al. (2016)

Collins (2014) 
entirely displayed pathological system of any advanced cancer, especially advanced breast cancer. Despite this, we think that the relationship between tumour growth and immune evasion can offer new therapeutic opportunities via an efficacious immune manipulation.

\section{Tumour growth and prognosis}

Several findings have highlighted the clinical relevance of proliferation signalling in breast cancer. In particular, few studies have shown its significant relationship with patient outcome. Luminal A, which is the most common molecular breast cancer subtype with a favourable prognosis, exhibits low expression of cell proliferationrelated genes compared with luminal B, which is characterized by a more aggressive phenotype and high expression of these genes (Galanina et al. 2011, Eroles et al. 2012). A high expression of cell proliferation-related genes is common in basal-like breast cancer (BLBC) or TNBC, associated with the worst prognosis among the different molecular subtypes (Perou et al. 2000). A PARADIGM analysis of basal-like vs luminal tumours demonstrated that hyperactivated FOXM1 is a transcriptional driver of this enhanced proliferation signature. Basal-like cancers have $80 \%$ of tumour suppressor protein (TP53) mutations; furthermore, the loss of retinoblastoma-associated protein (RB) 1 and BRCA1 genes and high phosphatidylinositol-3 kinase/protein kinase B (AKT) pathway activities are common features of this molecular subtype (Cancer Genome Atlas Network 2012). Moreover, a basal-specific trans-module enriched for transcriptional changes involving cell cycle, DNA damage repair and apoptosis and reflecting the high mitotic index typically associated with basal-like cancers has been described (Curtis et al. 2012). In two large-scale studies, a high ratio of the homeobox 13 to IL-17B receptor (IL-17BR) expression correlated with poor clinical outcome in resected nodenegative ER-positive breast cancer patients receiving adjuvant tamoxifen. Interestingly, IL-17BR plays a role in recurrences, either by the induction of anti-tumour immunity or by mediating the response to growth factors involved in breast epithelial tumour proliferation (Erlander et al. 2005, Goetz et al. 2006, 2008). In another study (Paik et al. 2004), the expression of 16 cancer-related and five reference genes were used to calculate a recurrence score (RS) for predicting the outcome of tamoxifen-treated, node-negative breast cancer patients. In a multivariate Cox model, the RS was significantly predictive of distant recurrence and overall survival (OS). In this study, the 16 selected genes were grouped on the basis of function, correlated expression or both. Two of the four groups, termed the proliferation and human epidermal growth factor receptor (HER)-2 groups, included five (KI67, STK15, survivin, CCNB1 and MYBL2) and two (GRB7, and Her2) of the 16 selected genes, respectively. Therefore, approximately half of the genes used to calculate the RS were directly related to tumour growth. In a successive investigation, the same RS was prognostic for tamoxifentreated node-positive breast cancer patients and predicted a significant response to chemotherapy in patients with a high RS (Albain et al. 2010).

\section{Immune signatures and prognosis}

Recently, well-described immune signatures have been reported in many studies on gene expression. Specifically, some prognostic immune signatures have been developed for HER-2+ ER- $\alpha-$, TNBC or BLBC. This is of particular relevance as these breast cancers are among the molecular subtypes that are the most aggressive and resistant to therapy. In the studies on HER-2+ ER- $\alpha$ - breast cancers (Liu et al. 2012, 2017), the developed 17-gene immune signature, in addition to the high prognostic value, allowed the identification of patients who would benefit from combination therapy with trastuzumab and immunomodulatory drugs. A biological networkdriven gene selection in TNBC (Bonsang-Kitzis et al. 2015) identified a stromal six metagene signature named immunity 1, immunity 2, proliferation/DNA damage, androgen receptor-like, Matrix/Invasion 1 and Matrix 2 clusters with the immunity two metagene having a high positive prognostic value. In a study on BLBC (MartínezCanales et al. 2017), 16 genes associated with immune function and upregulated in BLBC compared with their expression in normal breast tissue were linked with improved clinical outcome. In particular, the association of upregulated HLA/T-cell immunoreceptor with IG and ITIM (TIGIT) domains and HLA-C/HLA-F/TIGIT genes showed the most favourable outcome. In other two studies, the immune signature predicted benefit from trastuzumab in adjuvant (Perez et al. 2015) or neoadjuvant (Varadan et al. 2016) settings. Interestingly, in these and other studies (Levy et al. 2016, Heimes et al. 2017, Kim et al. 2017), when immunological signature was associated with immune function and immune response, it directly correlated with a better clinical outcome. Moreover, epigenetic alterations, in addition to the genetic alterations, of immune genes with prognostic impact have been increasingly reported in different types of cancers, including breast cancer. In an investigational study 
(Xu et al. 2016), all 10 B7 family members were amplified in breast cancer. In particular, B7 mRNA levels were upregulated in a cohort of 1098 patients with different types of breast cancer and in 82 patients with TNBC. Promoter methylation analysis showed an epigenetic basis for the deregulation of certain B7 family genes, and only B7-H6 amplification was significantly associated with worse OS. In a further experimental study (Jeschke et al. 2017), DNA methylation markers were profiled to identify a methylation of tumour-infiltrating lymphocyte (MeTIL) signature. The MeTIL signature measured TIL distribution in a sensitive way and predicted improved survival and response to chemotherapy in breast cancer better than the histopathological evaluation of TILs or gene expressionbased immune markers. Tables 2 and 3 summarize the prognostic role of proliferation and immune signatures.

\section{Relationships between tumour growth and immune evasion}

\section{Experimental studies}

An increasing number of recent experimental studies have reported proliferation and tumour growth to be closely linked to immune evasion in breast cancer. A few of them are briefly described here. In one experimental study, tumour growth was found to be largely COX dependent through immune evasion, thus supporting COX activity as a driver of immune suppression (Zelenay et al. 2015). This observation has been confirmed by another experimental investigation, where mammary carcinoma cell-derived COX 2 was found to suppress tumour immune surveillance by enhancing intra-tumoural immune checkpoint activity. In the same study, the examined v-erb-b2 avian erythroblastic leukaemia viral oncogene homolog 2 (ErbB2) transgenic mice that were deficient in mammary epithelial cell COX-2 (COX-2 MEC-KO mice) showed the decreased expression of Ki 67, a proliferation marker, and contained more CD4+ Th cells and CD8+ cytotoxic immune cells compared with wild-type mice, indicating enhanced immune surveillance. Moreover, in ErbB2-transformed mouse breast cancer cells, where lentiviral shRNA delivery was used to knock down COX-2, growth was strongly suppressed (Markosyan et al. 2013). The results of another study (Loi et al. 2016) suggested that Ras-mitogen-activated protein kinase (MAPK) pathway activation induces immune evasion in TNBC. In particular, genetic or transcriptomic alterations in Ras-MAPK signalling were significantly correlated with lower TILs. Moreover, MEK inhibition upregulated cell surface MHC expression and PD-L1 in TNBC cells both in vivo and in vitro. In a different study (Zhang et al. 2015a), hypoxia-inducible factor 1 directly upregulated the transcription of $\mathrm{CD} 47$ expression in breast cancer cells, promoting the evasion of phagocytosis by macrophages and the maintenance of CSCs. In another study (Olesch et al. 2015), microsomal prostaglandin E synthase (mPGES-1/2) in human and mouse models of breast cancer was shown to favour immune evasion. In addition, mPGES-1 inhibition increased CD80 expression by tumour-associated phagocytes, which triggered cytotoxic T-cell activation and restricted tumour growth. A downregulation of miR-148a, which is closely involved in cancer cell proliferation, has been reported in both ER-positive breast cancer and TNBC. An experimental investigation (Tao et al. 2014) has validated the hypothesis that E2 downregulates miR-148a through C protein-coupled oestrogen receptor-1 (GPER) and that E2 also affects the expression of HLA-G, which is an miR-148a target gene. Therefore, a new mechanism based on the ability of oestrogenic GPER signalling to trigger HLA-G expression through the inhibition of miR-148a, which supports immune evasion in breast cancer, has been elucidated. Epidermal growth factor receptor (EGFR) signalling is often dysregulated in TNBC and is also associated with increased glycolysis. A study focused on these aspects (Lim et al. 2016) showed that the increased aerobic glycolysis induced by EGFR signalling

Table 2 Prognostic clinical relevance of proliferation signatures in breast cancer.

\begin{tabular}{|c|c|c|}
\hline BC subtype/subgroup & Expression & Prognosis \\
\hline Luminal A vs luminal B & Lower in luminal A vs luminal B & Better \\
\hline Basal-like/TNBC & High & Worst \\
\hline $\mathrm{N}-\mathrm{ER}+$ & High HOXB13 to IL-17BR ratio & Poor \\
\hline TAM treated $\mathrm{N}-$ or $\mathrm{N}+$ & $\begin{array}{l}\text { High RS with } 16 \text { selected genes, } 7 \text { of them } \\
\text { being proliferation (5) or HER2 ( } 2 \text { ) } \\
\text { related genes }\end{array}$ & Poor \\
\hline
\end{tabular}

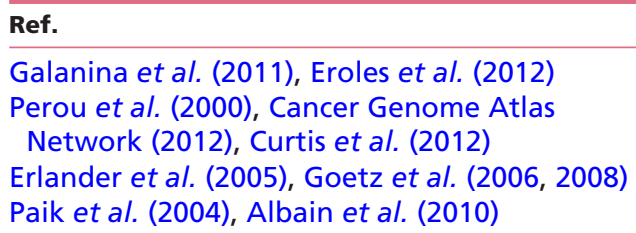

Ref.

Galanina et al. (2011), Eroles et al. (2012) Perou et al. (2000), Cancer Genome Atlas Network (2012), Curtis et al. (2012) Erlander et al. (2005), Goetz et al. (2006, 2008) Paik et al. (2004), Albain et al. (2010)

ER+, ER-alpha positive; HOXB13, homeobox13; IL-17BR, interleukin-17 B receptor; $\mathrm{N}-$ or N+, axillary lymph-node negative or positive; TAM, tamoxifen; TNBC, triple-negative breast cancer (also see text). 
Table 3 Immune signatures and prognosis in breast cancer.

\begin{tabular}{|c|c|}
\hline BC subtype/subgroup & Type of immune signature \\
\hline HER2+ & $\begin{array}{l}\text { Immune index increase after brief } \\
\text { exposure to trastuzumab }\end{array}$ \\
\hline Early HER2+ & $\begin{array}{l}9 \text { or more of } 14 \text { immune function gene } \\
\text { enriched tumours }\end{array}$ \\
\hline HER2+ REalpha- & $\begin{array}{l}\text { 17-Gene HER2-TIC-enriched signature } \\
\text { (HTICS+)* }\end{array}$ \\
\hline BLBC & $\begin{array}{l}\text { HLA-F/TIGIT and HLA-C/HLA-F/TIGIT } \\
\text { upregulated genes }\end{array}$ \\
\hline TNBC & $\begin{array}{l}\text { Weak immunity two metagene } \\
\text { expression }\end{array}$ \\
\hline TNBC, luminal, HER2+ & High Metil score \\
\hline
\end{tabular}

Prognosis
Better response (to
neoadjuvant $\mathrm{CT}+\mathrm{H}$ )
Benefit (from adjuvant $\mathrm{H}$ )
Benefit (from adjuvant $\mathrm{CT}+\mathrm{H}$ )
Significantly better DFS and OS

Poor DSS

Better outcome
Ref.

Varadan et al. (2016)

Perez et al. (2015)

Liu et al. $(2012,2017)$

Martínez-Canales et al. (2017)

Bonsang-Kitzis et al. (2015)

Jeschke et al. (2017)

*This signature includes genes related to cell proliferation, immune response and cell migration.

BLBC, basal-like breast cancer; CT, chemotherapy; DSS, disease-specific survival; $H$, trastuzumab; HLA, human leukocyte antigen; Metil, methylation of tumour-infiltrating lymphocytes; OS, overall survival; RFS, relapse free survival; TIC, tumour-initiating cells; TIGIT, T-cell immune receptor with IG and ITIM domains; TNBC, triple-negative breast cancer (also see text).

in TNBC promotes cell proliferation and tumour growth accompanied by immune escape. In a MMTV-HER2/neu mouse mammary tumour-initiating cells (TICs) model, a 17-gene HER2-TIC-enriched signature (HTICS) predicted the clinical outcome in multiple independent HER2+ cohorts. Four of the eight upregulated genes in HTICS were involved directly in cell cycle progression, DNA replication and mitosis. The upregulation of these genes was concomitant with the downregulation of genes involved in immune response, thus favouring immune evasion (Liu et al. 2012).

\section{Clinical studies in metastatic breast cancer with an undetectable or detectable non-growing tumour burden following conventional therapy}

In the last decade, we have reported very promising results (Nicolini \& Carpi 2005, Nicolini et al. 2005, 2007, 2008) and the possible rationale (Nicolini et al. 2006, Nicolini \& Carpi 2009) of an open pilot clinical study using a new schedule of conventional anti-oestrogen therapy combined with immune stimulation. We have more times published both results (Nicolini \& Carpi 2005, Nicolini et al. 2014a) and their interpretation (Nicolini et al. 2014b, 2015, 2016). Progression-free survival (PFS) and median OS times since the diagnosis of distant metastases in 31 endocrine-dependent breast cancer patients were 33 and 94 months, respectively. In 24 of these patients with high levels of hormone dependency (55\% of ER-positive progesterone (Pgr)-positive), the median OS was 98.5 months and the delayed median PFS was 45 months compared with those in the remaining seven subjects with lower hormone dependency (20\% of ER+ Pgr+), in whom the median OS was 37 months and the median PFS was 20 months. It is noteworthy that $16 \%$ of the patients have survived for more than 10 years in complete remission. The following mechanistic interpretation has been proposed: 'within the TME, stromal cells, infiltrating lymphocytes and tumour cells foster tumour growth and immune evasion through a complex network of autocrine and paracrine loops mediated by cytokines and growth factors'. In an anti-oestrogen-responsive metastatic disease, a stable or decreased tumour burden and a lower genetic instability due to quiescent state (G0-G1 state) of tumour cells are also likely to reduce immune evasion by the downregulation of immune escape and immune inhibition. This favours the immune attack stimulated by the sequential administration of IFN- $\beta$ and IL- 2 , which, by synergizing with anti-oestrogen therapy, can delay hormone resistance and clinically result into a prolonged response or stable disease. The larger the tumour working portion, the higher its biological aggressiveness. In those with shorter median survival and a likely lower hormone dependence, an expected greater and more aggressive portion of the tumour burden worked with a higher production of cytokines and growth factors. This can explain the earlier occurrence and perhaps more effective immune inhibition during the progression of metastatic disease in those surviving for $<5$ years. On the other hand, in those surviving for $>5$ years and with higher levels of hormone dependence, an expected smaller and probably less aggressive portion of the tumour burden worked with lower production of cytokines and growth factors. This may have permitted the immune system to work more effectively for a longer time. Moreover, during the clinical benefit, we showed that 'laboratory evidence of the effect of immunotherapy as well as that hormone resistance occurs at the progression of the disease concomitantly 
with a laboratory pattern compatible with immune inhibition' (Nicolini et al. 2007, 2016). We have recently published the last update on the issue (Nicolini et al. 2018). In another pilot study, a maintenance immunotherapy with low-dose IL2 and 13-cis retinoic acid was administered to 100 consecutive metastatic breast cancer patients with a clinical benefit (complete response $(\mathrm{CR})+$ partial response $(\mathrm{PR})+$ stable disease $(\mathrm{SD})$ ) from 6 to 8 courses of induction chemotherapy. There were $68 \mathrm{ER}+$ and/or Pgr+ patients, all of whom, after the induction of chemotherapy, received endocrine therapy with luteinizing hormone-releasing hormone (LHRH) analogues or letrozole in addition to the maintenance immunotherapy according to whether they were pre- or post-menopausal. In the 100 patients, the median PFS and OS were 37.1 and 57.5 months, respectively. PFS and OS were 44.7 and 64.5, respectively, in the 68 patients with ER+ tumours compared with 32.7 and 51.4, respectively, in the 23 patients with ER- tumours (Recchia et al. 2008). In this study, the authors highlighted 'a sustained improvement in lymphocytes, NKs and CD4+/CD8+ ratio with respect to baseline values'. In an earlier pilot study from the same research group, a maintenance immunotherapy with IFN- $\beta$, retinyl palmitate and tamoxifen until progression was administered to 23 metastatic breast cancer patients who had achieved a clinical response (11 CR and $12 \mathrm{PR}$ ) following six courses of induction and two successive courses of consolidation chemotherapy. All the 23 patients were unresponsive to the hormonal therapy. The PFS and OS were 31.4 and 44 months, respectively, in the 23 responders $(\mathrm{CR}+\mathrm{PR})$. The OS was 66 months (with 9-year survival rate of 34\%) in the 11 complete responders and 17 months in the nonresponders (seven with $\mathrm{SD}$ and six with progressive disease) (Recchia et al. 1998). The reported median OS in ER+ Her2-negative metastatic breast cancer is 25 months (Savci-Heijink et al. 2015) to 30.6 months (Zielinski et al. 2016). In these last two pilot studies, the median OS was longer than expected in similar populations and was even longer in the two subsets of ER+ and complete responders (64.5 and 66 months, respectively). However, in these two subsets, the median OS was shorter than just reported (94 months). Indeed, in our pilot study, all the patients were selected because they showed a clinical benefit during anti-oestrogen therapy before receiving the additional immune therapy (Nicolini \& Carpi 2005). In the first of the last two pilot studies, all the $68 \mathrm{ER}+$ patients received maintenance immunotherapy without any previous clinical evaluation of response to the hormone therapy. In the latter, all 23 of the recruited patients were unresponsive to the hormone therapy. In these two last pilot studies, the authors clearly refer to the welldocumented immune modulation in addition to the antiproliferative action by IFNs and retinoids. In particular, the capacity of retinoids to increase the number of IL-2 receptors and peripheral blood lymphoid cells expressing the surface markers of Th cells (Prabhala et al. 1991) is mentioned. Moreover, the function of retinoids, which is to facilitate the differentiation of immature myeloid suppressor cells (Gr1+ CD115-), is reported (Huang et al. 2006). The biological activity of retinoids is mediated by nuclear retinoic acid receptors (RARs) and retinoid $\mathrm{X}$ receptors (RXRs), which are ligand-activated transcription factors and are basally present in breast cancer cells. More recently, the relevant role of retinoids for breast cancer chemoprevention and treatment because of their ability to induce cell differentiation and growth suppression (Garattini et al. 2014, Seo et al. 2015) has been highlighted. Although ER+ breast tumours are also RAR sensitive and are mainly activated by all trans-retinoic acid and 13-cisretinoic acid (Garattini et al. 2014), RXRs are critical for the growth of ER- breast cancer cells (Uray \& Brown 2011) and are targeted by a special class of retinoids called rexinoids (Uray \& Brown 2011, Seo et al. 2015). Table 4 summarizes the data from these three studies. Another study (Greenberg et al. 1996) has reported the long-term outcome of 1581 metastatic breast cancer patients from 18 successive front-line trials conducted from 1973 to 1982 at the University of Texas, MD Anderson Cancer Center. All the patients received induction-phase and maintenance chemotherapy that was usually continued for 2 years. The analysis identified 26 (1.6\%) patients who were potentially cured among the 1581 evaluated individuals. In fact, they remained in first complete remission after a median duration of 191 months. All 26 of these patients participated along with 263 subjects who had achieved complete remission on anthracyclinecyclophosphamide-based front-line chemotherapy; comparison of the 26 patients with the overall 263 complete responders and total patient populations showed that they had an initially lower tumour burden. In the above-described studies, a longer than expected clinical benefit and OS were observed in patients with or without an immune modulation and/or active immune stimulation following response to the conventional antiproliferative treatment: anti-oestrogens or conventional cytotoxic chemotherapy. In all of these studies, a low tumour burden was associated with a better clinical outcome; in some of these studies, laboratory data showed that immune therapy stimulated the immune response. 


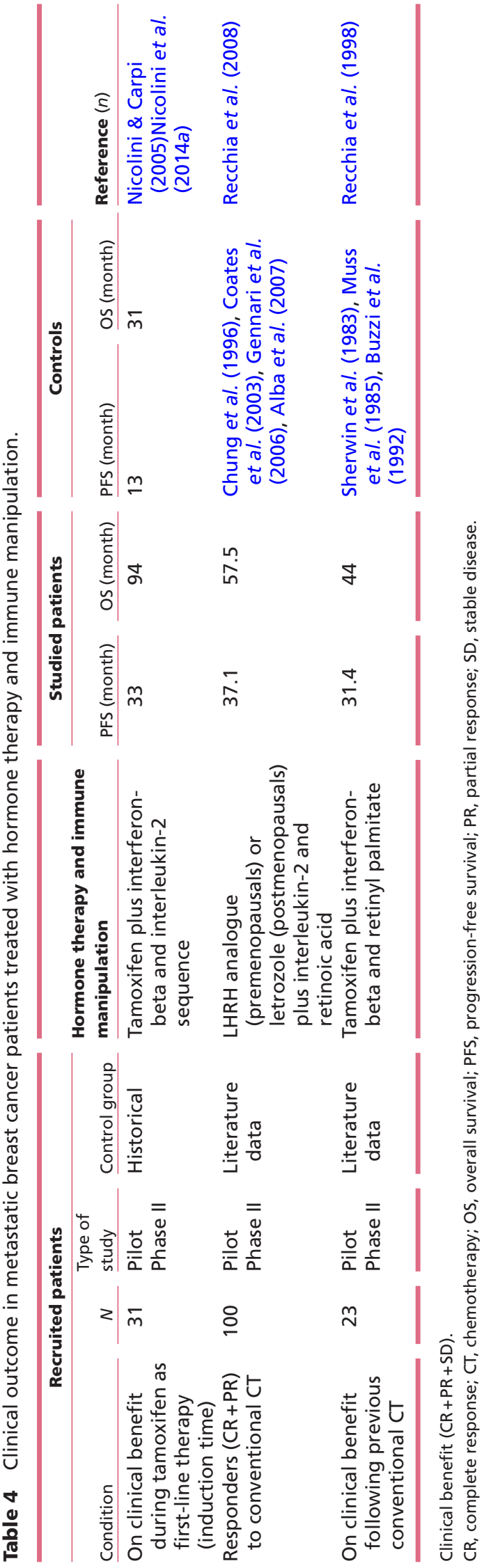

http://erc.endocrinology-journals.org https://doi.org/10.1530/ERC-18-0142 (c) 2018 Society for Endocrinology Published by Bioscientifica Ltd. Printed in Great Britain

\section{Clinical studies in lung, ovarian and colorectal cancers}

Here, we summarize clinical studies in advanced cancers other than breast cancer, which contribute to the understanding of the relationships of tumour burden with clinical outcome and likely with immune surveillance (Table 5). The studies can be clustered into two groups. The first group includes studies on a population of patients showing a clinical benefit $(\mathrm{CR}+\mathrm{PR}+\mathrm{SD})$ following conventional chemotherapy. The other group includes studies on patients with an undetectable residual metastatic disease following radical resection.

\section{Patients with an undetectable or detectable non- growing metastatic tumour burden following conventional chemotherapy}

In this subgroup, three studies conducted by Recchia et al. can be included. In two phase II studies on advanced ovarian and advanced non-small-cell lung cancer, IL-2 and 13-cis retinoic acid, respectively, were given as maintenance therapy to patients responsive to and with measurable metastatic disease after conventional chemotherapy. In the advanced ovarian cancer trial, 96\% of the patients receiving immune maintenance treatment were responders, 64\% of whom showed CR (Recchia et al. 2005); in the other study (Recchia et al. 2006), 53\% of the patients were the responders, only $6 \%$ of whom showed CR. In both studies, the remaining patients had $\mathrm{SD}$. The above-described immune maintenance treatment was cyclically self-administered by educated patients and 2 months was considered to represent a single cycle of therapy. The PFS and OS were the secondary end points for comparison with historical data from controls who were chosen to perfectly match the patients in the study group. The PFS and OS curves showed a statistically significant improvement in IL-2/13-cis retinoic acid-treated patients. For example, in the advanced ovarian cancer trial, the median PFS and OS were 50.5 and 102.5 months, respectively, in the study group compared with 15.5 and 29.6 months, respectively, in the controls. In the advanced non-small-cell lung cancer trial, the median PFS and OS were 16.5 and 23.4 months, respectively, in the study group compared with 8.4 and 11.8 months, respectively, in the controls. Another investigation using the same schedule of immunotherapy was conducted by the same research group in metastatic colorectal cancer patients who had a clinical benefit $(\mathrm{CR}+\mathrm{PR}+\mathrm{SD})$ from induction chemotherapy (Recchia et al. 2006). In this study, 
Table 5 Clinical relevance of tumour burden for an active or probably induced immune manipulation in cancer other than breast.

\begin{tabular}{|c|c|c|c|c|c|c|}
\hline \multirow[b]{2}{*}{ Tumour burden } & \multirow[b]{2}{*}{ Cancer type } & \multirow[b]{2}{*}{ Pts, $n(\%)$} & \multirow[b]{2}{*}{ Immune-manipulation } & \multicolumn{2}{|c|}{ Clinical outcome (month) } & \multirow[b]{2}{*}{ References } \\
\hline & & & & $\begin{array}{l}\text { PFS/DFS (median; } \\
\text { month) }\end{array}$ & $\begin{array}{l}\text { OS (median; } \\
\text { month) }\end{array}$ & \\
\hline \multirow{4}{*}{$\begin{array}{l}\text { Undetectable (CR } \\
\text { or radical } \\
\text { surgery) or } \\
\text { detectable (PR, } \\
\text { SD) not growing } \\
\text { disease } \\
\text { following } \\
\text { conventional CT }\end{array}$} & Ovary* & $\begin{array}{l}C R, 88(64) \\
P R, 14(32) \\
S D, 2(4)\end{array}$ & IL-2 plus 13 -cis-RA & $\begin{array}{l}50.5 \text { vs } 15.5 \\
\text { (controls) } \\
P<0.00012 * * *\end{array}$ & $\begin{array}{l}\text { All } 102.5 \text { vs } \\
29.6 \\
\text { (controls) } \\
P<0.0001 * * *\end{array}$ & $\begin{array}{l}\text { Recchia et al. } \\
\text { (2005) }\end{array}$ \\
\hline & $\begin{array}{l}\text { Lung* } \\
\text { (non-small) }\end{array}$ & $\begin{array}{l}C R, 3(6) \\
P R, 17(34) \\
S D, 18(36)\end{array}$ & IL-2 plus $13-$ cis-RA & $\begin{array}{l}16.5 \text { vs } 8.4 \\
\text { (controls) } \\
P<0.0003^{* * *}\end{array}$ & $\begin{array}{l}\text { All } 23.4 \text { vs } \\
11.8 \\
\text { (controls) } \\
P<0.0007^{* * *}\end{array}$ & $\begin{array}{l}\text { Recchia et al. } \\
\text { (2006) }\end{array}$ \\
\hline & Colon* & $\begin{array}{l}C R, 10(25) \\
P R, 11(27) \\
S D, 19(48)\end{array}$ & IL-2 plus $13-$ cis-RA & $\begin{array}{l}27.8 \text { vs } 12.5 \\
\text { (controls) } \\
P<0.0001^{* * *}\end{array}$ & $\begin{array}{l}\text { All } 52.9 \text { vs } \\
20.2 \\
\text { (controls) } \\
P<0.0001 * * *\end{array}$ & $\begin{array}{l}\text { Recchia et al. } \\
\text { (2006) }\end{array}$ \\
\hline & $\mathrm{Gl} *$ (mixed) & $19(100)$ & $\begin{array}{l}\text { Few cycles of additional } \\
\text { conventional CT } \\
\text { regularly given }\end{array}$ & $\begin{array}{l}80.4 \% 5 \text {-year vs } \\
31.8 \% \text { expected }\end{array}$ & $\begin{array}{l}87.1 \% 5 \text {-year } \\
\text { vs } 40.1 \\
\text { expected }\end{array}$ & $\begin{array}{l}\text { Nicolini et al. } \\
(2010)\end{array}$ \\
\hline \multirow{5}{*}{$\begin{array}{l}\text { Undetectable (m. } \\
\text { r. d.) following } \\
\text { radical surgery } \\
\text { with or without } \\
\text { adjuvant CT }\end{array}$} & Colorectal & $1001(100)$ & $\begin{array}{l}\text { No active immune- } \\
\text { manipulation }\end{array}$ & NA & $22 \% 10$-year & $\begin{array}{l}\text { Fong et al. } \\
\text { (1999) }\end{array}$ \\
\hline & & $173(100)$ & & NA & 27\% 10-year & $\begin{array}{l}\text { Scheele et al. } \\
\text { (1990) }\end{array}$ \\
\hline & & $\begin{array}{l}86 \text { with CT }(100) \\
85 \text { without CT }(100)\end{array}$ & & $\begin{array}{l}\text { DFS and 5-year } \\
\text { DFS } \\
24.4 \text { and } 33.5 \% \\
\text { vs } 17.6 \text { and } \\
26.5 \% \\
\text { (controls) } \\
P=0.028\end{array}$ & $\begin{array}{l}\text { OS and } \\
5 \text {-year OS } \\
62.1 \text { and } \\
51.1 \% \\
\text { vs } 46.4 \text { and } \\
41.1 \% \\
\text { (controls) } \\
P=0.13\end{array}$ & $\begin{array}{l}\text { Portier et al. } \\
\text { (2006) }\end{array}$ \\
\hline & & $\begin{array}{l}138 \text { with } C T(100) \\
140 \text { without } C T \\
(100)\end{array}$ & & $\begin{array}{l}\text { PFS and 5-year } \\
\text { DFS } \\
27.9 \text { and } 36.7 \% \\
\text { vs } 18.8 \text { and } \\
27.7 \% \\
\text { (controls) } \\
P=0.058\end{array}$ & $\begin{array}{l}\text { OS and } \\
5 \text {-year OS } \\
62.2 \text { and } \\
52.8 \% \text { vs } \\
47.3 \text { and } \\
39.6 \% \\
\text { (controls) } \\
P=0.095\end{array}$ & $\begin{array}{l}\text { Mitry et al. } \\
\text { (2008) }\end{array}$ \\
\hline & & $\begin{array}{l}6254 * *(100) \\
\quad \text { (meta-analysis) }\end{array}$ & & $\begin{array}{l}\text { 5-year DFS ranging } \\
46 \%\end{array}$ & $g$ from $13 \%$ to & $\begin{array}{l}\text { Liu et al. } \\
\text { (2016) }\end{array}$ \\
\hline
\end{tabular}

*pilot study; **neoadjuvant $\mathrm{CT}$ prior to hepatic resection; ***log-rank test.

13-cis-RA, 13-cis-retinoic acid; CR, complete response; CT, chemotherapy; DFS, disease-free survival; GI, gastrointestinal; HT, hormone therapy; IL-2, interleukin-2; m. r. d., minimal residual disease; NA, not available; OS, overall survival; PFS, progression-free survival; PR, partial response; SD, stable disease (also see text).

$25 \%$ were complete responders. After a median follow-up of 36 months, the median PFS was 27.8 months in the 40 recruited patients of the study group and 12.5 months in the 80 controls. The median OS was 52.9 in the study group and 20.2 in the controls. In all the three pilot trials, the number of total lymphocytes, NK cells, CD4+/CD8+ ratio and VEGF were determined in the peripheral blood of both the studied patients and controls. At baseline in all three studies, none of the evaluated immunological parameters in the two treatment groups (studied patients and controls) were statistically different. In the ovarian cancer study, a progressive increase in the lymphocyte count in IL-2-treated patients and a progressive decrease in the controls was observed, and the difference after 1 year became statistically significant in both the lung and colorectal cancer studies $(P<0.01$ and $P<0.0001$, respectively). Similarly, the NK cells increased in IL-2treated patients compared with that in the controls, and after 1 and 2 years (ovarian cancer study) or 1 year (lung and colorectal cancer studies) the difference became statistically significant $(P=0.03$ and $P=0.0007$ for ovarian cancer; $P=0.04$ and $P<0.0001$ for lung and colorectal cancer, respectively). Again, in all the three studies, the CD4+/CD8+ ratio values increased in IL2-treated patients 
and decreased in controls; after 1 and 2 years (ovarian cancer study) or 1 year (lung and colorectal cancer studies), the difference became statistically significant within the same group before and after maintenance immunotherapy and between them (IL-2 treated vs controls). Finally, in all the three studies, the baseline VEGF values of IL-2-treated patients showed a statistically significant decrease after 1 year (lung cancer study, $P=0.0002$ ). In the other two studies, the same significant decrease was maintained at 1 and 2 years (ovarian cancer study, $P<0.0049$; colorectal cancer study, $P<0.0001)$. Unlike in responding patients, in those progressing during conventional chemotherapy, immunotherapy is more likely unsuccessful. In fact, in one of two recently published clinical trials conducted in advanced non-small-cell lung cancer using immune checkpoint (CTL antigen 4, PD-1 and PD L1) inhibitors, a $30 \%$ increase in PFS (3.5 vs 2.8 months) has been reported compared with the conventional chemotherapy (Brahmer et al. 2015); in the other, without PFS improvement, there was a 30\% increase in the OS (12.2 vs 9.4 months) (Borghaei et al. 2015). In the same target population of advanced non-small-cell lung cancer in the previously mentioned experimental trial conducted by Recchia et al. (2006), the significant PFS and OS improvement observed in patients treated with IL-2 and 13-cis retinoic acid maintenance therapy was $100 \%$ (8.4 vs 16.5 months and 11.8 vs 23.4 months, respectively) compared with that in the controls. However, in the pilot study by Recchia et al., the patients were recruited in clinical benefit, whereas in those conducted with the new immunological drugs; the patients were recruited when they were in progression following previous conventional therapy. Thus, this different condition at the time of recruitment may have substantially affected the outcome. Overall, these findings suggest that an appropriate immune maintenance therapy can significantly improve the clinical outcome of patients with a detectable non-growing metastatic tumour burden. This improvement seems to be correlated with the proportion of complete responders to conventional chemotherapy, i.e., with the tumour burden.

\section{Patients with gastrointestinal (GI) cancer and an undetectable residual metastatic disease following radical surgery}

In a pilot study conducted by a group (Nicolini et al. 2010) in patients with GI cancers who were apparently disease free after primary surgery and had a high risk of relapse due to residual undetectable metastases, an almost double 5-year disease-free survival (DFS; 80.4\%) and OS (87.1\%) was reported compared with the expected. In this study, starting from the first year after conventional adjuvant chemotherapy till the fifth year, patients received 2-3 cycles of additional adjuvant chemotherapy using infusional 5-fluorouracil (FU) plus leucovorin. Moreover, it has been reported that $22-27 \%$ of colorectal cancer patients are 10-year survivors following radical resection of synchronous or metachronous liver metastases without any adjuvant chemotherapy (Scheele et al. 1990, Fong et al. 1999). Conventional adjuvant or neoadjuvant chemotherapy commonly with infusional 5-FU plus leucovorin significantly increased the 5-year DFS rate from $27-42 \%$ to $37-46 \%$ (Portier et al. 2006, Mitry et al. 2008, Liu et al. 2016). It is noteworthy that the extension of primary tumour and liver recurrences were among the most significant predictors of worse prognosis in all the trials and that only about $20 \%$ of colorectal cancer patients are chemosensitive to infusional 5-FU plus leucovorin (Nicolini et al. 1998). In patients with an undetectable minimal residual disease, an induced or spontaneous recovery of the immune surveillance can be predicted. An undetectable or detectable non-growing tumour burden following conventional chemotherapy and an undetectable minimal residual metastatic disease following radical surgery are more suitable conditions for immune manipulation. The former condition, which likely occurred in our study and other mentioned pilot studies, benefited from an actively induced immune stimulation or immune maintenance therapy that improved the clinical outcome. Interestingly, in this condition, a prolonged 'resting state' (G0-G1 state) was likely due to the hormone therapy allowing more efficacious immune manipulation and better clinical outcome. In addition to the already mentioned immunemodulating properties of retinoids and preclinical evidence (Moon et al. 1983, Sporn \& Roberts 1983) of their key role in controlling normal cellular proliferation and differentiation, it is well known that IL-2 is the principal growth factor for lymphocytes (Nicolini et al. 2006). In addition, there is clinical evidence (Lippman et al. 1992, Frasci et al. 1993, The Nordic Myeloma Study Group 1996) supporting the efficacy of IFN therapy combined with conventional chemotherapy or retinoids in the settings of locally advanced or minimal residual disease of breast and other types of cancer. In the latter case, the reduction by surgical removal and/or a conventional anti-proliferative therapy of a previously well-detectable and extended cancer to minimally undetectable residual metastatic disease could have favoured the spontaneous recovery of the immune surveillance. This maintained 
a small fraction of these patients in the disease-free and potentially healthy state. Lower residual metastatic tumour burden, chemosensitivity and other not yet wellunderstood reasons likely led to the selection of this small fraction of patients. This suggests that tumour burden and proliferation directly correlate with immune evasion and with the complexity of the activated network that sustains each cancer. The concept of a link between tumour burden and immune tolerance is also gaining acceptance within the scientific community (Cimino-Mathews et al. 2015, Clifton et al. 2015, Migali et al. 2016).

\section{A refined pathobiological model and a novel therapeutic strategy}

In prolonged 'resting state' (G0-G1 state) non-growing condition during anti-oestrogen therapy (Osborne 1994, Wolf et al. 1994, Doisneau-Sixou et al. 2003) or in the 'minimal residual metastatic disease' molecular pathways promoting invasion and diffusion, angiogenesis and reprogramming energy and metabolism are likely downregulated, without clinical relevance. This is consistent with the finding that the rate of definitely cured patients after adjuvant therapy and/or primary operation is inversely correlated with tumour size at diagnosis. Accordingly, angiogenesis and metastatic processes are strictly linked to the progression of cancer and the shift from an oxidative to glycolytic metabolism, mainly through the 'Warburg effect', is favoured by hypoxia concomitant with tumour growth. Therefore, following these and the previously reported data and concepts about the relationship between tumour growth and immune evasion, we propose to refine the pathobiological model by Hanahan and Weinberg, as shown in Fig. 1. By this model, long-term active antiproliferative therapies and minimal residual disease are the conditions mostly favouring an efficacious immune manipulation.

\section{Endocrine-dependent cancers}

Recently, the genetic background of proliferationpromoting and -inhibiting action of oestrogens and antioestrogens, respectively, has been evaluated in-depth, and the immunosuppressive function of sex hormones has been largely documented. These findings are summarized below.

\section{ER- $\alpha$-regulated genes in MCF-7 human breast cancer cell lines increase tumour growth}

ER- $\alpha$ is a transcription factor that regulates many genes that play important roles in physiology and are also involved in the development and progression of breast cancer. MCF-7 cells have shown that although ER- $\alpha$ interacts with thousands of genomic regions, E2-responsive genes range from 100 to 1500 (Charpentier et al. 2000,

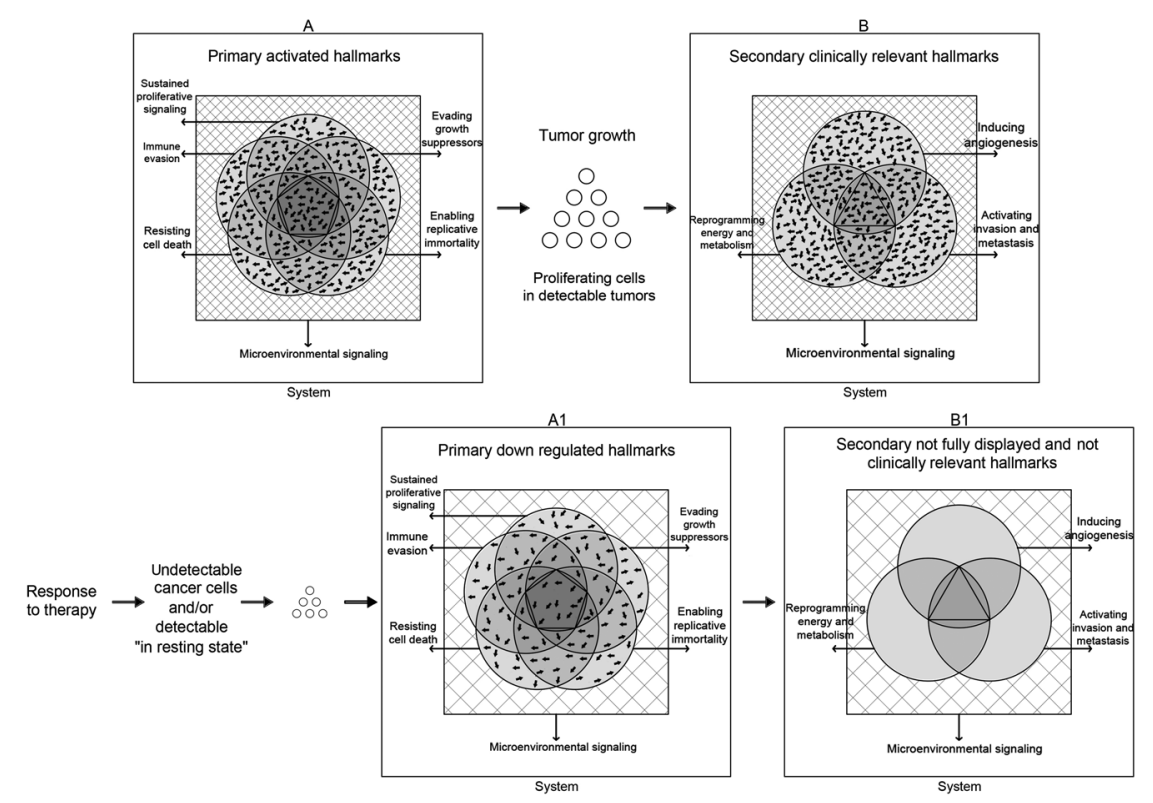

Figure 1

A refined pathobiological model for advanced breast cancer, relationship of tumour growth with immune evasion. ( $A$ and $B$ ) Any sphere represents an activated subcircuit sustained by a pathological molecular network (short arrows) converging to the hallmarks (long arrows). The different activated pathological molecular networks at least in part overlap each other (in shadow areas); the square represents the signalling (grid) from a supportive tumour microenvironment cross-talking with the subcircuits; both pentagon and triangle represent active genomic instability and inflammation (additional integrated hallmarks). (A1 and B1) Any sphere represent a downregulated subcircuit; the different pathological molecular networks at least in part overlap each other (in shadow areas); the square represents the downregulated cross-talk of the microenvironment (grid) with the subcircuits; both pentagon and triangle represent the downregulated genomic instability and inflammation. Reprinted from Cell, vol 144, D Hanahan \& RA Weinberg, Hallmarks of cancer: the next generation, pages $646-674$, copyright (2011), with permission from Elsevier. 
Coser et al. 2003, Frasor et al. 2003, Carroll et al. 2006, Kininis et al. 2007, Lin et al. 2007). In previous study, Frasor et al. (2003) summarized their findings and stated that 'many genes whose expression is altered by E2 are associated with specific cell signalling pathways and regulatory factor receptor loops. These include a general upregulation of positive proliferation regulators and the downregulation of negative proliferation regulators, which together may contribute to the overall stimulation of proliferation and suppression of apoptosis'. Welboren used ChIP-Seq to map ER- $\alpha$-binding sites and to profile changes in RNA polymerase II occupancy in MCF-7 cells in response to E2, tamoxifen or fulvestrant (Welboren et al. 2009). Overall, 1256 genes and five different clusters of genes were identified. In particular, many genes encoded proteins binding the nucleus and RNA binding the mitochondrion. Moreover, E2 induced the downregulation of pro-apoptotic genes Bad, Bak, Bik and cyclin A and of genes involved in cell cycle arrest or proliferation, such as cyclin G2, a negative regulator of the cell cycle that maintains cells in a quiescent state. Cyclin D1 and IGF-binding protein 4 were the other regulated genes governing cell proliferation and growth. In another more recent study (Hah et al. 2011), the authors demonstrated 'a potent effect of E2 signalling on the protein biosynthetic machinery, which fits well with the known mitogenic effects of E2 on MCF-7 cells' and highlighted that 'E2 signalling has strong, immediate and likely direct effects on transcription by all three RNA polymerases'. In a research study (Kininis et al. 2007) aimed at exploring the global mechanisms of oestrogenregulated transcription, the authors reported that 'many of these direct E2 target genes exhibit interesting modes of regulation and biological activities, some of which may be relevant to onset and proliferation of breast cancers (e.g. UGT2B15, CYP1B1 and PRUSE)'. In a review article following the above report, the same authors (Hah \& Kraus 2014) concluded that 'the most immediate effects of oestrogen signalling on the genome results in the regulation of mRNAs encoding proteins involved in transcription, nucleic acid metabolism, and G protein-coupled and cell surface signalling. Thus, oestrogen signalling propagates the hormone-dependent transcriptional response, leading to secondary and sustained effects. Over the long term, oestrogen signalling upregulates the protein biosynthesis machinery. This is likely how the oestrogen signalling pathway prepares the cell for translation of the mRNAs that are newly synthesized in response to oestrogen signalling. The immediate and sustained effects of oestrogen signalling underlie the mitogenic effects of oestrogen signalling in breast cancers' (Fig. 2).

\section{Tamoxifen inhibits most ER- $\alpha$-mediated proliferation genes}

In a study conducted by Frasor et al. (2004), the effects of different SERMs were investigated in MCF-7 cells. Based on the results, the authors stated that it is apparent that many of the genes on which the SERMs act as antagonists could affect cell proliferation' and that 'their ability to block the E2 stimulation of cell proliferation suggests that the genes they antagonize are those that are essential for the stimulatory effect of E2 on cell proliferation'. They concluded that 'it is of interest that several of these genes have potential tumour suppressor or anti-proliferative activities in breast cancer cells and could contribute to the beneficial effects of transhydroxytamoxifen'. A successive investigation by the same author focused on genes not or minimally regulated by E2 and preferentially regulated by tamoxifen in ER- $\alpha$-positive MCF-7 human breast cancer cells (Frasor et al. 2006). Among the 64 genes preferentially regulated by tamoxifen (50 upregulated

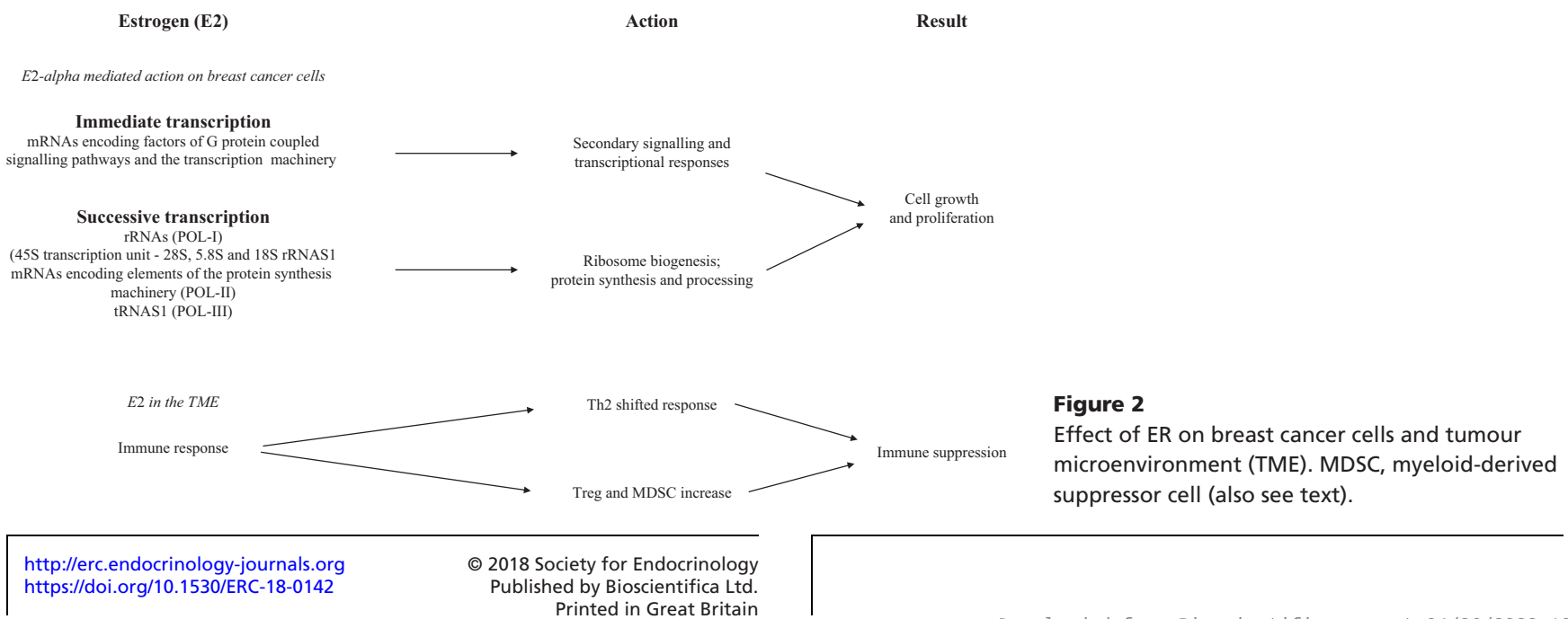


and 14 downregulated) were PKIA, an inhibitor of cyclic AMP-dependent protein kinase A activity; PTPRG, a receptor type protein tyrosine phosphatase; and SOCS1, an inhibitor of JAK/STAT signalling; PTPRG and SOCS1 have potential tumour suppressor roles. All have the capacity 'to alter different cellular signalling pathways and, thus, responsiveness of breast cancer cells to other hormones, growth factors or cytokines. In addition, IEX1 has been shown to have growth-inhibitory effect suggestive of a beneficial effect of tamoxifen'. Two tamoxifen upregulated genes, namely YWHAZ and LOC441453, showed significant association with disease recurrence. YWHAZ likely plays a relevant role in insulin receptor and EGFR signalling and in cell cycle regulation. Overall, the findings reported in the two studies by Frasor were confirmed in another study by Welboren et al. (2009). In this successive research, most of the E2-upregulated genes were antagonized by tamoxifen, which mainly showed agonistic behaviour on E2-downregulated genes. In addition, a group of genes was the only target of tamoxifen. Table 6 summarizes the gene ontology of tamoxifen ER- $\alpha$ mediated genes assessed in some principal studies. The studies performed recently and mentioned above show that genes that are mostly affected by oestrogens and anti-oestrogens are proliferation genes.

\section{Sex hormones and the immune response}

Reportedly, testosterone has a general suppressive effect on the immune function (Roved et al. 2017). In particular, testosterone has dampening effects on many innate immune cells (monocytes, macrophages, dendritic cells (DCs), granulocytes, NK cells, platelets and endothelial cells) and in DCs, it may also downregulate the expression of MHC class II receptors and co-stimulatory molecules (Koh et al. 2009, Hepworth et al. 2010). Regarding adaptive immunity, its action on type 1 (Th1) response is uncertain, whereas a significant decrease in type 2 and Th17-induced immune responses due to the suppression of functions associated with Th2 and Th17 differentiation has been reported (Hepworth et al. 2010, Yao et al. 2003, Kissick et al. 2014). Th1 cells mostly activate macrophages and CD8+ CTLs, whereas Th2 cells mainly stimulate B cells to produce antibodies and Th17 cells to produce inflammatory cytokines (particularly IL-17 and IL-22) (Murphy \& Weaver 2016). Regarding estrogens and adaptive immunity, Foo et al. in a meta-analysis of 38 studies (Foo et al. 2017) found that oestrogens induce positive effects on humoral immunity but a significantly decreased effect on cell-mediated immunity. In particular, oestrogens shift adaptive immune responses in favour of type 2 immune responses (Faas et al. 2000), whereas type 1 and Th-17 responses are suppressed (Wang et al. 2009, Tyagi et al. 2012, Chen et al. 2015a,b). Data suggesting the promoting or inhibiting role of Th-17 and IL-17 on tumorigenesis have been reported. Some findings (Alinejad et al. 2017) have suggested that through activation of the ERK1/ERK2,NF-kb and BCL-2 pathways, theIL-17B/IL-17RB system promotes inflammation, breast cancer progression as well as resistance to chemotherapy drugs (Alinejad et al. 2016). Conversely, some findings have shown that IL-17 significantly induce MDSC differentiation, inhibit their proliferation and trigger apoptosis through the JAK/STAT3 pathway in vitro (Ma et al. 2018), whereas other findings (Benchetrit et al. 2002, Kryczek et al. 2009) have supported an anti-tumour effect against certain tumours. A recent review (Rothenberger et al. 2018) focusing on the role of the oestrogen pathway in the TME has confirmed that oestrogen promotes immune suppression through the modulation of pro-tumour responses independent of direct activity on tumour cells (Fig. 2). In particular, data have suggested that oestrogens in the TME 'shift the balance in favour of $\mathrm{Th} 2$ responses, production of tumourpromoting cytokines (IL-6, IL-4, TNF- $\alpha$ and IL-17A) and M2 TAM infiltration compared to the Th1 responses, associated Th1 cytokines (IL-12 and IFN $\gamma$ ) and M1 TAM infiltration'. Moreover, oestrogens are likely 'to promote tumour immune evasion through the proliferation of Treg cell and MDSC populations, augmented tumour cell PD-L1 expression and inhibition of CD8+ T-cell- and NK cell-induced apoptosis. In addition, CAFs may support the TME by providing paracrine sources of oestrogens and IL-6'. All these studies have clarified that many genes and, consequently, multiple molecular pathways whether directly or indirectly involved in breast cancer proliferation are induced by oestrogens and inhibited by anti-oestrogens. This, in addition to the relevant role of anti-oestrogens in inhibiting an immune-suppressive TME, promoted by oestrogens, makes them ideal candidates in the battle against cancer either alone or in combination with other drugs (Rothenberger et al. 2018).

\section{Locally advanced or metastatic disease}

A successful immune manipulation is more probable in patients with metastatic disease in clinical benefit during anti-oestrogen therapy. In fact, anti-oestrogens, by directly acting on multiple genes or indirectly inhibiting proliferation, promote a prolonged 'resting state' (G0-G1 state) (Osborne 1994, Wolf et al. 1994, 


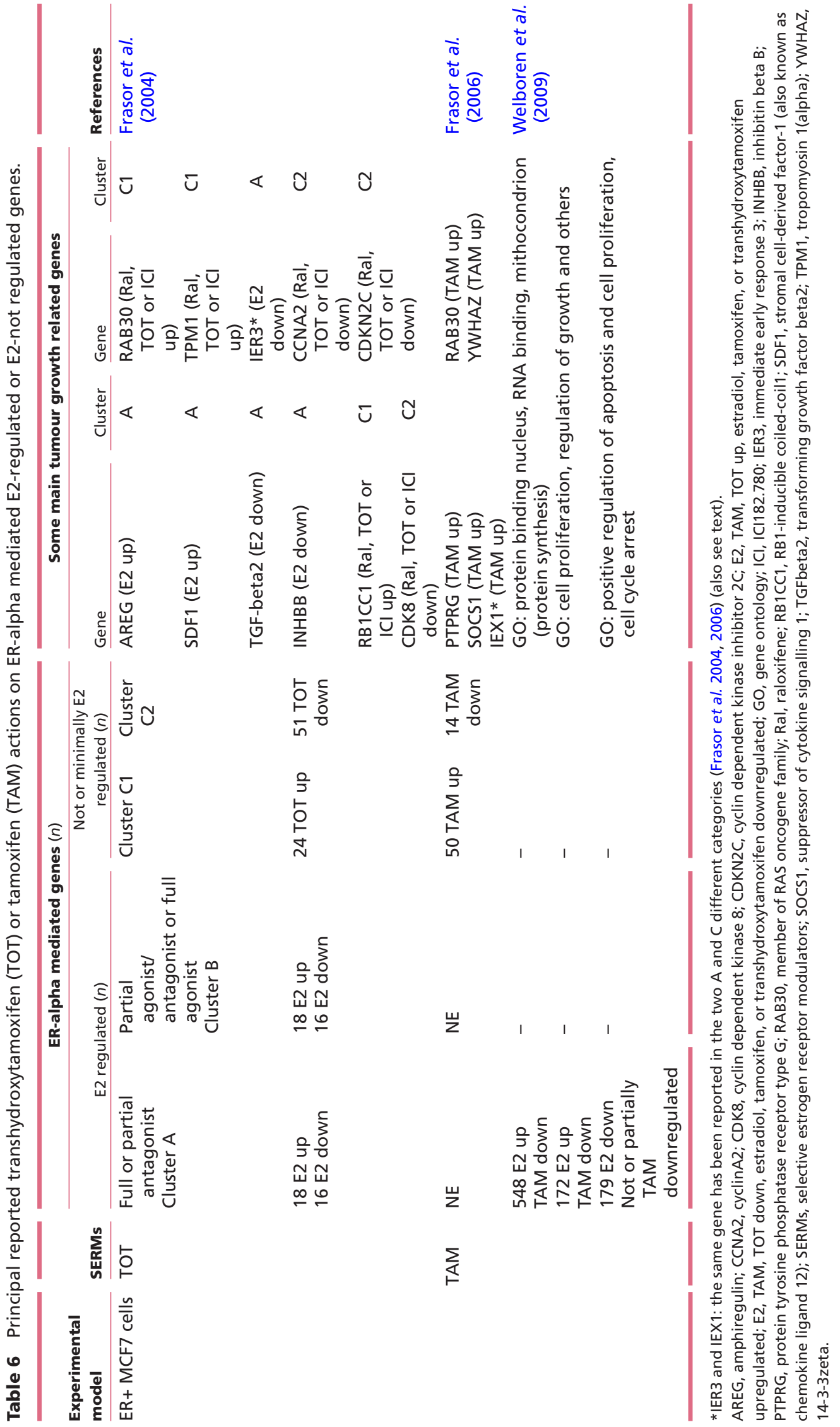


Doisneau-Sixou et al. 2003) concomitant with a nongrowing tumour (clinical benefit) or a decrease in tumour burden to 'minimal residual metastatic disease' (CR). The probable concomitant downregulation of the multiple mechanisms responsible for immune tolerance permit an active immune modulation/stimulation, which, as reported above in the work of our group and other authors, significantly prolong the PFS and/or OS. Thus, first, in ER-positive metastatic breast cancers, the same schedules of immune-modulatory/stimulatory treatments combined with anti-oestrogens should be validated in large prospective randomized trials. Moreover, in the same population of ER-positive patients but with locally advanced cancer, they should be investigated as adjuvant treatments. The combination of hormone therapy with immunotherapy could be considered for the same duration for which conventional anti-oestrogens are currently recommended (5-7 years). It can be inferred that by replacing conventional anti-oestrogens with antiandrogens, the same schedules of hormone immune therapies proposed in endocrine-dependent breast cancer could be evaluated in metastatic and locally advanced hormone-dependent prostate cancers.

\section{Endocrine-independent cancers at high risk of relapse}

\section{Locally advanced}

In endocrine-dependent cancers with de novo or acquired hormone resistance and other types of high-risk endocrine-independent solid cancers (gastrointestinal, lung and ovary), it is currently unproven and unlikely to obtain a prolonged 'resting state' of resistant cancer cells. In these patients, conventional anti-proliferative drugs and/or therapeutic interventions (surgical and/or radiological) should aim to decrease the tumour burden as much as possible. In patients with locally advanced cancer and postoperative minimally residual disease, the analysis of proliferation markers Ki67 and p120 have shown that approximately $16 \%$ of disseminated tumour cells are in an active cell cycle, whereas the majority remain arrested in G0 phase (Pantel et al. 1993). Tumour dormancy and the concomitant multi-drug resistance in the chemosensitivity test can explain the frequent inefficacy of adjuvant chemotherapy. In dormant cells, a gradual proliferation can be triggered by the changes in their microenvironment and/or the acquisition of additional genetic 'hits' (Köstler et al. 2000). Thus, in these patients, in the initial 6-8 months after conventional adjuvant chemotherapy and/or radical resection, regular administration of a few cycles (3-4) of anti-proliferative drugs with concomitant immune-modulating properties, such as taxanes or antimetabolites (5-FU, capecitabine), at low doses every 8-12 months for a few years can be considered (Nicolini et al. 2010). In fact, it is likely that at least a few months are needed for residual resistant cancer cells to grow and activate the multiple concomitant mechanisms necessary to mount a significant immune tolerance in these patients. Thus, the main aim of this additional adjuvant chemotherapy is to interrupt the probable 'works in progress'. In fact, this procedure is expected to gradually switch off the mechanisms triggering the proliferation of residual resistant cancer cells and the concomitant immune evasion. Paclitaxel administered once a week for

Table 7 Proposal of a novel therapeutic strategy for advanced breast and other cancers treatment.

\begin{tabular}{|c|c|c|c|c|c|}
\hline Setting & Target population & Therapeutical interventions & Main aim & Cancer type & Reference \\
\hline $\begin{array}{l}\text { Adjuvant at high } \\
\text { risk or metastatic }\end{array}$ & Endocrine responsive* & $\begin{array}{l}\text { Large prospective randomized } \\
\text { multicenter trials with } \\
\text { hormone-immunotherapy }\end{array}$ & $\begin{array}{l}\text { Significant PFS } \\
\text { and/or OS } \\
\text { increase }\end{array}$ & $\begin{array}{l}\text { Breast and } \\
\text { Prostate }\end{array}$ & $\begin{array}{l}\text { Nicolini et al. } \\
(2014 a)\end{array}$ \\
\hline $\begin{array}{l}\text { Adjuvant at } \\
\text { high risk }\end{array}$ & $\begin{array}{l}\text { Endocrine } \\
\text { resistant/independent } \\
\text { likely with m.r. d. }\end{array}$ & $\begin{array}{l}3-4^{* *} \text { cycles of taxanes or } \\
\text { antimetabolites (5-FU, } \\
\text { capecitabine) with or without } \\
\text { partially synergizing immune } \\
\text { drugs regularly given every } 8-12 \\
\text { months, for } 5 \text { years }\end{array}$ & $\begin{array}{l}\text { Significant delay } \\
\text { or decrease of } \\
\text { the recurrence } \\
\text { rate }\end{array}$ & $\begin{array}{l}\text { Breast and } \\
\text { other solid } \\
\text { tumours }\end{array}$ & $\begin{array}{l}\text { Recchia et al. } \\
\text { (1998, 2006, } \\
\text { 2007), } \\
\text { Nicolini } \\
\text { et al. (2010) }\end{array}$ \\
\hline $\begin{array}{l}\text { Metastatic in CR, } \\
\text { PR or SD following } \\
\text { conventional CT }\end{array}$ & $\begin{array}{l}\text { Endocrine } \\
\text { resistant/independent } \\
\text { with detectable } \\
\text { metastatic disease }\end{array}$ & $\begin{array}{l}\text { Immunomodulatory and/or } \\
\text { immunostimulating drugs }\end{array}$ & $\begin{array}{l}\text { To delay } \\
\text { metastatic } \\
\text { progression }\end{array}$ & & \\
\hline
\end{tabular}

*In prostate cancer, anti-androgens replace anti-estrogens; **taxanes or antimetabolites (5-FU, capecitabine) should be chosen in relation to cancer type (breast and other solid cancers) according with current therapeutic recommendations.

CR, complete response; m. r. d., minimal residual disease; OS, overall survival; PFS, progression-free survival; PR, partial response; SD, stable disease. 
A

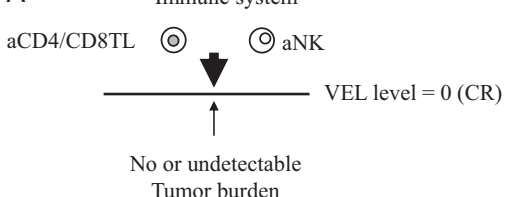

B

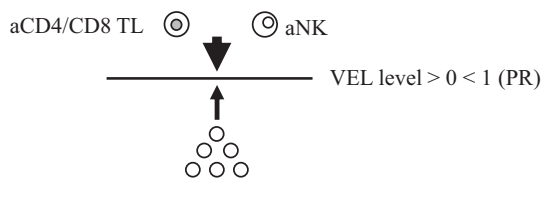

Q/RRCCs
C Immune system

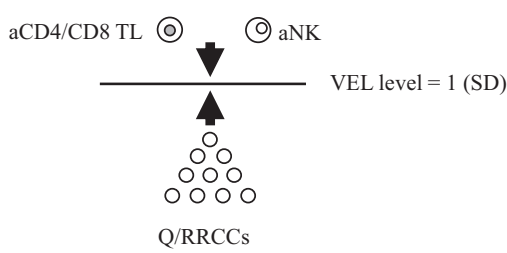

D Immune system

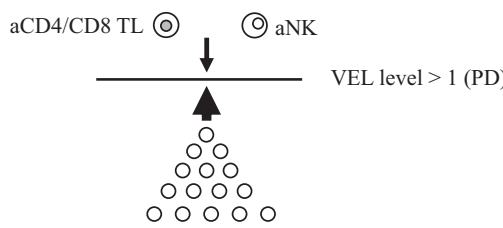

00000

Q/RRCCs
Figure 3

Different levels of a virtual equilibrium line (VEL) in tumours with undetectable burden or with prolonged 'resting state' of residual cancer cells following conventional therapy. (A) CR: immune system strongly prevails and eliminates all or most Q/RRCCs; (B) PR: immune system prevails and eliminates any new formed cancer cell but only some Q/RRCCs; (C) SD: a perfect equilibrium occurs and immune system eliminates any new formed cancer cell but no Q/RRCCs; (D) PD: immune system eliminates less new cancer cells than they are formed by Q/RRCCs (also see text). aCD4/CD8TL, activated CD4/CD8 T lymphocyte; aNK, activated NK cell; Q/RRCCs, quiescent/ resistant residual cancer cells; VEL, virtual equilibrium line.
2 weeks every 3 weeks or 5-FU infusion administered for 5 days every 28 days ( 1 cycle) blocks MDSC expansion in addition to the well-known anti-proliferative effect (Sevko et al. 2012). Low dose of paclitaxel also has been reported to simultaneously inhibit Treg cells (Sevko et al. 2012) and exert immune-stimulatory effects on DCs at ultralow doses (Shurin et al. 2009). On the other hand, 5-FU can counter one or more ways of immune attack evasion by tumour cells, such as downregulation of MHC class I antigens, loss of Fas expression and shedding of tumour antigens (Khallouf et al. 2012). Potentially synergizing immune drugs, such as IFNs, IL-2 and retinoids, can be included. These therapeutic schedules could significantly delay or decrease recurrences, as shown in GI cancers (Nicolini et al. 2010).

\section{Metastasis in clinical benefit during conventional therapy}

In cases of resistant/non-endocrine-dependent breast and other types of solid cancers in clinical benefit $(\mathrm{CR}+\mathrm{PR}+\mathrm{SD})$ following conventional therapy, immune maintenance therapy (immunomodulatory/stimulating drugs) can be attempted to delay the regrowth of tumour. In these cases, provided that immune tolerance is directly correlated with tumour burden (Migali et al. 2016), more therapeutic effect is expected when immune manipulation follows CR or PR rather than SD (Recchia et al. 2005, 2006, 2007). Table 7 summarizes these proposals.

\section{A virtual equilibrium line between tumour burden and the immune system}

In patients with undetectable or prolonged quiescent/ non-growing state of residual cancer cells, the efficacy of the immune response (cure of the disease or delay of the occurrence of resistance to therapy) can be determined by the level at which a virtual equilibrium line is positioned by the opposite activities of cancer and immune cells. In fact, under these conditions, the tumour burden is balanced between the actions from residual resistant cancer cells and the spontaneously or actively modulated/ stimulated immune response. The pressure exerted by the resistant proliferating cancer cells can be successfully or not counterbalanced by the immune response. When a CR occurs, it is likely that the spontaneously induced or actively stimulated immune system prevails so that most or all of the residual resistant cancer cells are eliminated and the equilibrium line is positioned at level 0 . When a PR occurs, the immune system is likely to inhibit the formation of or eliminate any new cancer cells and only some of the residual resistant cancer cells; therefore, the line is positioned at level $>0<1$. When a SD occurs, a perfect equilibrium is established and the immune system inhibits the formation of or eliminates any new cancer cells, but not residual resistant cancer cells, and the line remains at level 1 . In case of a disease progression, the activated immune system likely eliminates new cancer cells less than they are derived from the residual resistant cancer cells, and the equilibrium line is positioned at level $>1$. Any factor that affects the immune activation, the amount of residual resistant cancer cells and their phenotype can change the position of the equilibrium line (Fig. 3).

\section{Conclusions}

In this article, the recent major advances acquired in molecular biology of cancer were the premise to discuss the apparent discrepancy in the poor prognosis of advanced 
breast cancer. In reality, it has become increasingly clear that advanced cancer, especially advanced breast cancer, is an entirely displayed pathological system that is much more complex than previously considered. Thus, the understanding of cancer is a work in continuous progress. General rules governing the entirely displayed pathological cancer system, if existing, should be identified. Experimental and clinical studies on breast cancer and other types of cancer support the notion of a close relationship between tumour growth and immune evasion. Based on these findings, we propose a novel therapeutic strategy and a refined pathobiological model for advanced breast and other solid cancers. The novel therapeutic strategy is based on therapeutically induced conditions (undetectable tumour burden or a prolonged tumour 'resting state'), which enable an efficacious immune response in advanced breast and other types of solid cancers.

\section{Declaration of interest}

The authors declare that there is no conflict of interest that could be perceived as prejudicing the impartiality of this review.

\section{Funding}

This work did not receive any specific grant from any funding agency in the public, commercial, or not-for-profit sector.

\section{Acknowledgements}

To Emilio Cardaci, Informatic Service, Department of Medical Area, University of Pisa, Dr Sara Russo, graduated in Architecture and Luigi Nicolini, for the technical assistance in the preparation of Fig.1. Authors also are thankful to Prof. Vikas P Sukhatme from Harvard Medical School, Boston, MA, for useful discussions.

\section{References}

Alba E, Ruiz-Borrego M, Martín M, Margelí M, Rodríguez-Lescure Á, Sánchez-Rovira P, Ruiz A, Ribelles N, Calvo E \& Casado A 2007 Prolongation of TTP by maintenance therapy with PLD in a multicenter phase III randomized trial following standard chemotherapy for MBC: GEICAM 2001-2001 study. Journal of Clinical Oncology 25 18S; abstract 1007.

Albain KS, Barlow WE, Shak S, Hortobagyi GN, Livingston RB, Yeh IT, Ravdin P, Bugarini R, Baehner FL, Davidson NE, et al. 2010 Prognostic and predictive value of the 21-gene recurrence score assay in postmenopausal women with node-positive, oestrogen-receptorpositive breast cancer on chemotherapy: a retrospective analysis of a randomised trial. Lancet Oncology 11 55-65. (https://doi.org/10.1016/ S1470-2045(09)70314-6)

Albacker LA, Wu J, Smith P, Warmuth M, Stephens PJ, Zhu P, Yu L \& Chmielecki J 2017 Loss of function JAK1 mutations occur at high frequency in cancers with microsatellite instability and are suggestive of immune evasion. PLOS ONE 12 e0176181. (https://doi. org/10.1371/journal.pone.0176181)
Alinejad V, Hossein Somi M, Baradaran B, Akbarzadeh P, Atyabi F, Kazerooni H, Samadi Kafil H, Aghebati Maleki L, Siah Mansouri H \& Yousefi M 2016 Co-delivery of IL17RB siRNA and doxorubicin by chitosan-based nanoparticles for enhanced anticancer efficacy in breast cancer cells. Biomedicine and Pharmacotherapy 83 229-240. (https://doi.org/10.1016/j.biopha.2016.06.037)

Alinejad V, Dolati S, Motallebnezhad M \& Yousefi M 2017 The role of IL17B-IL17RB signaling pathway in breast cancer. Biomedicine and Pharmacotherapy 88 795-803. (https://doi.org/10.1016/j. biopha.2017.01.120)

Armstrong MJ, Stang MT, Liu Y, Yan J, Pizzoferrato E \& Yim JH 2015 IRF-1 inhibits NF- $\mathrm{B}$ activity, suppresses TRAF2 and cIAP1 and induces breast cancer cell specific growth inhibition. Cancer Biology and Therapy 16 1029-1041. (https://doi.org/10.1080/15384047.2015. 1046646)

Artero-Castro A, Perez-Alea M, Feliciano A, Leal JA, Genestar M, Castellvi J, Peg V, Ramón Y Cajal S \& Lleonart ME 2015 Disruption of the ribosomal P complex leads to stress-induced autophagy. Autophagy 11 1499-1519. (https://doi.org/10.1080/15548627.2015.10 63764)

Ascierto ML, De Giorgi V, Liu Q, Bedognetti D, Spivey TL, Murtas D, Uccellini L, Ayotte BD, Stroncek DF, Chouchane L, et al. 2011 An immunologic portrait of cancer. Journal of Translational Medicine $\mathbf{9}$ 146. (https://doi.org/10.1186/1479-5876-9-146)

Aziz MH, Chen X, Zhang Q, DeFrain C, Osland J, Luo Y, Shi X \& Yuan R 2015 Suppressing NRIP1 inhibits growth of breast cancer cells in vitro and in vivo. Oncotarget 6 39714-39724. (https://doi. org/10.18632/oncotarget.5356)

Bacac M, Provero P, Mayran N, Stehle JC, Fusco C \& Stamenkovic I 2006 A mouse stromal response to tumor invasion predicts prostate and breast cancer patient survival. PLOS ONE 1 e32. (https://doi. org/10.1371/journal.pone.0000032)

Benchetrit F, Ciree A, Vives V, Warnier G, Gey A, Sautès-Fridman C, Fossiez F, Haicheur N, Fridman WH \& Tartour E 2002 Interleukin-17 inhibits tumor cell growth by means of a T-cell-dependent mechanism. Blood 99 2114-2121. (https://doi.org/10.1182/blood. V99.6.2114)

Bergenfelz C, Larsson AM, von Stedingk K, Gruvberger-Saal S, Aaltonen K, Jansson S, Jernström H, Janols H, Wullt M, Bredberg A et al. 2015 Systemic monocytic-MDSCs are generated from monocytes and correlate with disease progression in breast cancer patients. PLOS ONE 10 e0127028. (https://doi.org/10.1371/journal. pone.0127028)

Bertoli G, Cava C \& Castiglioni I 2015 MicroRNAs: new biomarkers for diagnosis, prognosis, therapy prediction and therapeutic tools for breast cancer. Theranostics 5 1122-1143. (https://doi.org/10.7150/ thno.11543)

Bonsang-Kitzis H, Sadacca B, Hamy-Petit AS, Moarii M, Pinheiro A, Laurent C \& Reyal F 2015 Biological network-driven gene selection identifies a stromal immune module as a key determinant of triplenegative breast carcinoma prognosis. Oncoimmunology 5 e1061176. (https://doi.org/10.1080/2162402X.2015.1061176)

Borghaei H, Paz-Ares L, Horn L, Spigel DR, Steins M, Ready NE, Chow LQ, Vokes EE, Felip E, Holgado E, et al. 2015 Nivolumab versus docetaxel in advanced nonsquamous non-small-cell lung cancer. New England Journal of Medicine 373 1627-1639. (https://doi. org/10.1056/NEJMoa1507643)

Bouker KB, Skaar TC, Fernandez DR, O'Brien KA, Riggins RB, Cao D \& Clarke R 2014 Interferon regulatory factor-1 mediates the proapoptotic but not cell cycle arrest effects of the steroidal antiestrogen ICI 182,780 (faslodex, fulvestrant). Cancer Research 64 4030-4039. (https://doi.org/10.1158/0008-5472.CAN-03-3602)

Bowie ML, Dietze EC, Delrow J, Bean GR, Troch MM, Marjoram RJ \& Seewaldt VL 2004 Interferon-regulatory factor-1 is critical for tamoxifen-mediated apoptosis in human mammary epithelial cells. Oncogene 23 8743-8755. (https://doi.org/10.1038/sj.onc.1208120)
(C) 2018 Society for Endocrinology Published by Bioscientifica Ltd. Printed in Great Britain 
Brahmer J, Reckamp KL, Baas P, Crinò L, Eberhardt WE, Poddubskaya E, Antonia S, Pluzanski A, Vokes EE, Holgado E, et al. 2015 Nivolumab versus docetaxel in advanced squamous-cell non-small-cell lung cancer. New England Journal of Medicine 373 123-135. (https://doi. org/10.1056/NEJMoa1504627)

Bui JD \& Schreiber RD 2007 Cancer immunosurveillance, immunoediting and inflammation: independent or interdependent processes? Current Opinion in Immunology 19 203-208. (https://doi. org/10.1016/j.coi.2007.02.001)

Buzzi F, Brugia M, Rossi G, Giustini L, Scoponi C \& Sica G 1992 Combination of beta-interferon and tamoxifen as a new way to overcome clinical resistance to tamoxifen in advanced breast cancer. Anticancer Research 12 869-871.

Cancer Genome Atlas Network 2012 Comprehensive molecular portraits of human breast tumours. Nature 490 61-70. (https://doi. org/10.1038/nature11412)

Cao J, Xu G, Lan J, Huang Q, Tang Z \& Tian L 2016 High expression of piwi-like RNA-mediated gene silencing 1 is associated with poor prognosis via regulating transforming growth factor- $\beta$ receptors and cyclin-dependent kinases in breast cancer. Molecular Medicine Reports 13 2829-2835. (https://doi.org/10.3892/mmr.2016.4842)

Capietto AH, Martinet L \& Fournié JJ 2011 How tumors might withstand $\gamma \delta$ T-cell attack. Cellular and Molecular Life Sciences 68 2433-2442. (https://doi.org/10.1007/s00018-011-0705-7)

Cardoso F, Costa A, Senkus E, Aapro M, André F, Barrios CH, Bergh J, Bhattacharyya G, Biganzoli L, Cardoso MJ, et al. 2017 3rd ESO-ESMO international consensus guidelines for Advanced Breast Cancer (ABC3). Breast 31 244-259. (https://doi.org/10.1016/j. breast.2016.10.001)

Carroll JS, Meyer CA, Song J, Li W, Geistlinger TR, Eeckhoute J, Brodsky AS, Keeton EK, Fertuck KC, Hall GF, et al. 2006 Genomewide analysis of estrogen receptor binding sites. Nature Genetics $\mathbf{3 8}$ 1289-1297. (https://doi.org/10.1038/ng1901)

Charpentier AH, Bednarek AK, Daniel RL, Hawkins KA, Laflin KJ, Gaddis S, MacLeod MC \& Aldaz CM 2000 Effects of estrogen on global gene expression: identification of novel targets of estrogen action. Cancer Research 60 5977-5983.

Chen SY, Chiu LY, Maa MC, Wang JS, Chien CL \& Lin WW 2011 zVADinduced autophagic cell death requires c-Src-dependent ERK and JNK activation and reactive oxygen species generation. Autophagy 7 217-228. (https://doi.org/10.4161/auto.7.2.14212)

Chen LC, Lan H, Sun L, Deng YL, Tang KY \& Wan QH 2015a Genomic organization of the crested ibis MHC provides new insight into ancestral avian MHC structure. Scientific Reports 5 7963. (https://doi. org/10.1038/srep07963)

Chen RY, Fan YM, Zhang Q, Liu S, Li Q, Ke GL, Li C \& You Z 2015 b Estradiol inhibits Th17 cell differentiation through inhibition of ROR $\gamma \mathrm{T}$ transcription by recruiting the ER $\alpha /$ REA complex to estrogen response elements of the ROR $\gamma \mathrm{T}$ promoter. Journal of Immunology 194 4019-4028. (https://doi.org/10.4049/jimmunol.1400806)

Cheng YC, Rondón G, Sanchez LF, McMannis JD, Couriel DR, de Lima MJ, Hosing C, Khouri IF, Giralt SA, Champlin RE, et al. 2009 Interleukin-2 and granulocyte-macrophage-colony-stimulating factor immunomodulation with high-dose chemotherapy and autologous hematopoietic stem cell transplantation for patients with metastatic breast cancer. International Journal of Hematology 90 627-634. (https://doi.org/10.1007/s12185-009-0439-6)

Chia SK, Speers CH, D'yachkova Y, Kang A, Malfair-Taylor S, Barnett J, Coldman A, Gelmon KA, O'reilly SE, et al. 2007 The impact of new chemotherapeutic and hormone agents on survival in a populationbased cohort of women with metastatic breast cancer. Cancer $\mathbf{1 1 0}$ 973-979. (https://doi.org/10.1002/cncr.22867)

Chung M, Chang HR, Bland KI \& Wanebo HJ 1996 Younger women with breast carcinoma have a poorer prognosis than older women. Cancer 77 97-103. (https://doi.org/10.1002/(SICI)10970142(19960101)77:1<97::AID-CNCR16>3.0.CO;2-3)
Cimino-Mathews A, Foote JB \& Emens LA 2015 Immune targeting in breast cancer. Oncology 29 375-385.

Clarke R, Shajahan AN, Riggins RB, Cho Y, Crawford A, Xuan J, Wang Y, Zwart A, Nehra R \& Liu MC 2009 Gene network signaling in hormone responsiveness modifies apoptosis and autophagy in breast cancer cells. Journal of Steroid Biochemistry and Molecular Biology 114 8-20. (https://doi.org/10.1016/j.jsbmb.2008.12.023)

Clevers H 2004 At the crossroads of inflammation and cancer. Cell 118 671-674. (https://doi.org/10.1016/j.cell.2004.09.005)

Clifton GT, Mittendorf EA \& Peoples GE 2015 Adjuvant HER2/neu peptide cancer vaccines in breast cancer. Immunotherapy $\mathbf{7}$ 1159-1168. (https://doi.org/10.2217/imt.15.81)

Coates AS, Stockler MR \& Wilcken NRC 2003 Controversies in metastatic breast cancer: optimal duration of chemotherapy. American Society of Clinical Oncology Educational Book 21 119-121.

Coelho MA, de Carné Trécesson S, Rana S, Zecchin D, Moore C, MolinaArcas M, East P, Spencer-Dene B, Nye E, et al. 2017 Oncogenic RAS signaling promotes tumor immunoresistance by stabilizing PD-L1 mRNA. Immunity 47 1083.e6-1099.e6. (https://doi.org/10.1016/j. immuni.2017.11.016)

Collins JM 2014 Cancer pharmacology. In Abeloff's Clinical Oncology, 5th ed., pp 434-484. Eds JE Niederhuber, JO Armitage, JH Doroshow, MB Kastan, WW Shingleton \& JE Tepper. Philadelphia, PA, USA: ElsevierSaunders.

Cory S \& Adams JM 2002 The Bcl2 family: regulators of the cellular lifeor-death switch. Nature Reviews Cancer 2 647-656. (https://doi. org/10.1038/nrc883)

Coser KR, Chesnes J, Hur J, Ray S, Isselbacher KJ \& Shioda T 2003 Global analysis of ligand sensitivity of estrogen inducible and suppressible genes in MCF7/BUS breast cancer cells by DNA microarray. PNAS 100 13994-13999. (https://doi.org/10.1073/pnas.2235866100)

Couse JF \& Korach KS 1999 Estrogen receptor null mice: what have we learned and where will they lead us? Endocrine Reviews 20 358-417. (https://doi.org/10.1210/edrv.20.3.0370)

Curtis C, Shah SP, Chin SF, Turashvili G, Rueda OM, Dunning MJ, Speed D, Lynch AG, Samarajiwa S \& Yuan Y, et al. 2012 The genomic and transcriptomic architecture of 2000 breast tumours reveals novel subgroups. Nature 486 346-352. (https://doi.org/10.1038/ nature10983)

Davies MA \& Samuels Y 2010 Analysis of the genome to personalize therapy for melanoma. Oncogene 29 5545-5555. (https://doi. org/10.1038/onc.2010.323)

Dawood S, Broglio K, Gonzalez-Angulo AM, Buzdar AU, Hortobagyi GN \& Giordano SH 2008 Trends in survival over the past two decades among white and black patients with newly diagnosed stage IV breast cancer. Journal of Clinical Oncology 26 4891-4898. (https://doi. org/10.1200/JCO.2007.14.1168)

Doisneau-Sixou SF, Sergio CM, Carroll JS, Hui R, Musgrove EA \& Sutherland RL 2003 Estrogen and antiestrogen regulation of cell cycle progression in breast cancer cells. Endocrine-Related Cancer 10 179-186. (https://doi.org/10.1677/erc.0.0100179)

Dou L, Liang HF, Geller DA, Chen YF \& Chen XP 2014 The regulation role of interferon regulatory factor-1 gene and clinical relevance. Human Immunology 75 1110-1114. (https://doi.org/10.1016/j. humimm.2014.09.015)

Duffy MJ, Harbeck N, Nap M, Molina R, Nicolini A, Senkus E \& Cardoso F 2017 Clinical use of biomarkers in breast cancer: updated guidelines from the European Group on Tumor Markers (EGTM). European Journal of Cancer 75 284-298. (https://doi.org/10.1016/j. ejca.2017.01.017)

Eftekhari R, Esmaeili R, Mirzaei R, Bidad K, de Lima S, Ajami M, Shirzad H, Hadjati J \& Majidzadeh-A K 2017 Study of the tumor microenvironment during breast cancer progression. Cancer Cell International 17 123. (https://doi.org/10.1186/s12935-017-0492-9)

El Hasasna H, Athamneh K, Al Samri H, Karuvantevida N, Al Dhaheri Y, Hisaindee S, Ramadan G, Al Tamimi N, AbuQamar S, Eid A, et al. 
2015 Rhus coriaria induces senescence and autophagic cell death in breast cancer cells through a mechanism involving p38 and ERK1/2 activation. Scientific Reports 5 13013. (https://doi.org/10.1038/ srep13013)

Erlander MG, Ma XJ, Hilsenbeck SG, Sgroi DC, Osborne CK \& Allred DC 2005 Validation of HOXB13, IL17BR and $\mathrm{CHDH}$ as predictors of clinical outcome of adjuvant tamoxifen monotherapy in breast cancer. Breast Cancer Research and Treatment 94 S33-S34.

Eroles P, Bosch A, Pérez-Fidalgo JA \& Lluch A 2012 Molecular biology in breast cancer: intrinsic subtypes and signaling pathways. Cancer Treatment Reviews 38 698-707. (https://doi.org/10.1016/j. ctrv.2011.11.005)

Faas M, Bouman A, Moesa H, Heineman MJ, de Leij L \& Schuiling G 2000 The immune response during the luteal phase of the ovarian cycle: a Th2-type response? Fertility and Sterility 74 1008-1013. (https://doi.org/10.1016/S0015-0282(00)01553-3)

Farrugia MK, Sharma SB, Lin CC, McLaughlin SL, Vanderbilt DB, Ammer AG, Salkeni MA, Stoilov P, Agazie YM, Creighton CJ, et al. 2015 Regulation of anti-apoptotic signaling by Kruppel-like factors 4 and 5 mediates lapatinib resistance in breast cancer. Cell Death and Disease 6 e1699. (https://doi.org/10.1038/cddis.2015.65)

Ferlay J, Soerjomataram I, Dikshit R, Eser S, Mathers C, Rebelo M, Parkin DM, Forman D \& Bray F 2012 Cancer incidence and mortality worldwide: sources, methods and major patterns in GLOBOCAN 2012. International Journal of Cancer 136 E359-E386. (https://doi.org/10.1002/ijc.29210)

Fey D, Matallanas D, Rauch J, Rukhlenko OS \& Kholodenko BN 2016 The complexities and versatility of the RAS-to-ERK signalling system in normal and cancer cells. Seminars in Cell and Developmental Biology 58 96-107. (https://doi.org/10.1016/j.semcdb.2016.06.011)

Fong Y, Fortner J, Sun RL, Brennan MF \& Blumgart LH 1999 Clinical score for predicting recurrence after hepatic resection for metastatic colorectal cancer: analysis of 1001 consecutive cases. Annals of Surgery 230 309-318. (https://doi.org/10.1097/00000658-199909000$00004)$

Foo YZ, Nakagawa S, Rhodes G \& Simmons LW 2017 The effects of sex hormones on immune function: a meta-analysis. Biological Reviews of the Cambridge Philosophical Society 92 551-571. (https://doi. org/10.1111/brv.12243)

Frasci G, Tortoriello A, Facchini G, Conforti S, Cardone A, Persico G, Mastrantonio P \& Iaffaioli RV 1993 Intraperitoneal (ip) cisplatinmitoxantrone-interferon-alpha $2 \mathrm{~b}$ in ovarian cancer patients with minimal residual disease. Gynecologic Oncology 50 60-67. (https://doi. org/10.1006/gyno.1993.1165)

Frasor J, Danes JM, Komm B, Chang KC, Lyttle CR \& Katzenellenbogen BS 2003 Profiling of estrogen up- and downregulated gene expression in human breast cancer cells: insights into gene networks and pathways underlying estrogenic control of proliferation and cell phenotype. Endocrinology $1444562-4574$. (https://doi.org/10.1210/en.2003-0567)

Frasor J, Stossi F, Danes JM, Komm B, Lyttle CR \& Katzenellenbogen BS 2004 Selective estrogen receptor modulators: discrimination of agonistic versus antagonistic activities by gene expression profiling in breast cancer cells. Cancer Research 64 1522-1533. (https://doi. org/10.1158/0008-5472.CAN-03-3326)

Frasor J, Chang EC, Komm B, Lin CY, Vega VB, Liu ET, Miller LD, Smeds J, Bergh J \& Katzenellenbogen BS 2006 Gene expression preferentially regulated by tamoxifen in breast cancer cells and correlations with clinical outcome. Cancer Research 66 7334-7340. (https://doi.org/10.1158/0008-5472.CAN-05-4269)

Gál P, Varinská L, Fáber L, Novák Š, Szabo P, Mitrengová P, Mirossay A, Mučaji P \& Smetana K 2017 How signaling molecules regulate tumor microenvironment: parallels to wound repair. Molecules 22 E1818.

Galanina N, Bossuyt V \& Harris LN 2011 Molecular predictors of response to therapy for breast cancer. Cancer Journal 17 96-103. (https://doi.org/10.1097/PPO.0b013e318212dee3)
Galindo-Moreno M, Giráldez S, Sáez C, Japón MÁ, Tortolero M \& Romero F 2017 Both p62/SQSTM1-HDAC6-dependent autophagy and the aggresome pathway mediate CDK1 degradation in human breast cancer. Scientific Reports 7 10078. (https://doi.org/10.1038/ s41598-017-10506-8)

Gameiro SR, Malamas AS, Tsang KY, Ferrone S \& Hodge JW 2016 Inhibitors of histone deacetylase 1 reverse the immune evasion phenotype to enhance T-cell mediated lysis of prostate and breast carcinoma cells. Oncotarget 7 7390-7402. (https://doi.org/10.18632/ oncotarget.7180)

Gao J, Liu X, Yang F, Liu T, Yan Q \& Yang X 2015a By inhibiting Ras/ Raf/ERK and MMP-9, knockdown of EpCAM inhibits breast cancer cell growth and metastasis. Oncotarget 6 27187-27198. (https://doi. org/10.18632/oncotarget.4551)

Gao SP, Sun HF, Jiang HL, Li LD, Hu X, Xu XE \& Jin W 2015b Loss of COX5B inhibits proliferation and promotes senescence via mitochondrial dysfunction in breast cancer. Oncotarget 6 43363-43374. (https://doi.org/10.18632/oncotarget.6222)

Garattini E, Bolis M, Garattini SK, Fratelli M, Centritto F, Paroni G, Gianni M, Zanetti A, Pagani A, Fisher JN, et al. 2014 Retinoids and breast cancer: from basic studies to the clinic and back again. Cancer Treatment Reviews 40 739-749. (https://doi.org/10.1016/j. ctrv.2014.01.001)

Gennari A, Amadori D, De Lena M, Nanni O, Bruzzi P, Lorusso V, Manzione L \& Conte PF 2006 Lack of benefit of maintenance paclitaxel in first-line chemotherapy in metastatic breast cancer. Journal of Clinical Oncology 24 3912-3918. (https://doi.org/10.1200/ JCO.2006.06.1812)

Glodde N \& Hölzel M 2017 RAS and PD-L1: a masters' liaison in cancer immune evasion. Immunity 47 1007-1009. (https://doi.org/10.1016/j. immuni.2017.12.001)

Goetz MP, Suman VJ, Ingle JN, Nibbe AM, Visscher DW, Reynolds CA, Lingle WL, Erlander M, Ma XJ, Sgroi DC, et al. 2006 A two-gene expression ratio of homeobox 13 and interleukin-17B receptor for prediction of recurrence and survival in women receiving adjuvant tamoxifen. Clinical Cancer Research 12 2080-2087. (https://doi. org/10.1158/1078-0432.CCR-05-1263)

Goetz MP, Suman VJ, Couch FJ, Ames MM, Rae JM, Erlander MG, Ma XJ, Sgroi DC, Reynolds CA, et al. 2008 Cytochrome P450 2D6 and homeobox 13/interleukin-17B receptor: combining inherited and tumor gene markers for prediction of tamoxifen resistance. Clinical Cancer Research 14 5864-5868. (https://doi. org/10.1158/1078-0432.CCR-08-0619)

Granata S, Dalla Gassa A, Carraro A, Brunelli M, Stallone G, Lupo A, Zaza G 2016 Sirolimus and Everolimus pathway: reviewing candidate genes influencing their intracellular effects. International Journal of Molecular Sciences 17 E735. (https://doi.org/10.3390/ ijms17050735)

Greenberg PA, Hortobagyi GN, Smith TL, Ziegler LD, Frye DK \& Buzdar AU 1996 Long-term follow-up of patients with complete remission following combination chemotherapy for metastatic breast cancer. Journal of Clinical Oncology 14 2197-2205. (https://doi. org/10.1200/JCO.1996.14.8.2197)

Greten TF, Manns MP \& Korangy F 2011 Myeloid derived suppressor cells in human diseases. International Immunopharmacology $\mathbf{1 1}$ 802-807. (https://doi.org/10.1016/j.intimp.2011.01.003)

Hah N \& Kraus WL 2014 Hormone-regulated transcriptomes: lessons learned from estrogen signaling pathways in breast cancer cells. Molecular and Cellular Endocrinology 382 652-664. (https://doi. org/10.1016/j.mce.2013.06.021)

Hah N, Danko CG, Core L, Waterfall JJ, Siepel A, Lis JT \& Kraus WL 2011 A rapid, extensive, and transient transcriptional response to estrogen signaling in breast cancer cells. Cell 145 622-634. (https:// doi.org/10.1016/j.cell.2011.03.042)

Han Z, Jiang G, Zhang Y, Xu J, Chen C, Zhang L, Xu Z \& Du X 2015 Effects of RNA interference-mediated NRP-1 silencing on the 
proliferation and apoptosis of breast cancer cells. Molecular Medicine Reports 12 513-519. (https://doi.org/10.3892/mmr.2015.3405)

Han H, Li J, Feng X, Zhou H, Guo S \& Zhou W 2017a Autophagyrelated genes are induced by histone deacetylase inhibitor suberoylanilide hydroxamic acid via the activation of cathepsin B in human breast cancer cells. Oncotarget 8 53352-53365..(https://doi. org/10.18632/oncotarget.18410)

Han Q, Deng Y, Chen S, Chen R, Yang M, Zhang Z, Sun X, Wang W, He Y, Wang F, et al. 2017b Downregulation of ATG5-dependent macroautophagy by chaperone-mediated autophagy promotes breast cancer cell metastasis. Scientific Reports 7 4759. (https://doi. org/10.1038/s41598-017-04994-x)

Hanahan D \& Weinberg RA 2000 The hallmarks of cancer. Cell 100 57-70. (https://doi.org/10.1016/S0092-8674(00)81683-9)

Hanahan D \& Weinberg RA 2011 Hallmarks of cancer: the next generation. Cell 144 646-674. (https://doi.org/10.1016/j. cell.2011.02.013)

Hao NB, Lü MH, Fan YH, Cao YL, Zhang ZR \& Yang SM 2012 Macrophages in tumor microenvironments and the progression of tumors. Clinical and Developmental Immunology 2012948098. (https://doi.org/10.1155/2012/948098)

Heimes AS, Madjar K, Edlund K, Battista MJ, Almstedt K, Elger T, Krajnak S, Rahnenführer J, Brenner W, Hasenburg A, et al. 2017 Subtype-specific prognostic impact of different immune signatures in node-negative breast cancer. Breast Cancer Research and Treatment 165 293-300. (https://doi.org/10.1007/s10549-017-4327-0)

Heng B, Lim CK, Lovejoy DB, Bessede A, Gluch L \& Guillemin GJ 2016 Understanding the role of the kynurenine pathway in human breast cancer immunobiology. Oncotarget 7 6506-6520. (https://doi. org/10.18632/oncotarget.6467)

Hepworth MR, Hardman MJ \& Grencis RK 2010 The role of sex hormones in the development of Th2 immunity in a gender-biased model of Trichuris muris infection. European Journal of Immunology 40 406-416. (https://doi.org/10.1002/eji.200939589)

Hix LM, Shi YH, Brutkiewicz RR, Stein PL, Wang CR \& Zhang M 2011 CD1d-expressing breast cancer cells modulate NKT cell-mediated antitumor immunity in a murine model of breast cancer metastasis. PLOS ONE 6 e20702. (https://doi.org/10.1371/journal.pone.0020702)

Hou L, Chen L \& Fang L 2017 Scutellarin inhibits proliferation, invasion, and tumorigenicity in human breast cancer cells by regulating HIPPO-YAP signaling pathway. Medical Science Monitor 23 5130-5138. (https://doi.org/10.12659/MSM.904492)

Howell A, Anderson AS, Clarke RB, Duffy SW, Evans DG, GarciaClosas M, Gescher AJ, Key TJ, Saxton JM \& Harvie MN 2014 Risk determination and prevention of breast cancer. Breast Cancer Research 16 446. (https://doi.org/10.1186/s13058-014-0446-2)

Hu Z \& Xie L 2015 LHX6 inhibits breast cancer cell proliferation and invasion via repression of the Wnt/ $\beta$-catenin signaling pathway. Molecular Medicine Reports 12 4634-4639. (https://doi.org/10.3892/ mmr.2015.3997)

Huang B, Pan PY, Li Q, Sato AI, Levy DE, Bromberg J, Divino CM \& Chen SH 2006 Gr-1+CD115+ immature myeloid suppressor cells mediate the development of tumor-induced $\mathrm{T}$ regulatory cells and T-cell anergy in tumor-bearing host. Cancer Research 66 1123-1131. (https://doi.org/10.1158/0008-5472.CAN-05-1299)

Hugo H, Ackland ML, Blick T, Lawrence MG, Clements JA, Williams ED \& Thompson EW 2007 Epithelial-mesenchymal and mesenchymalepithelial transitions in carcinoma progression. Journal of Cellular Physiology 213 374-383. (https://doi.org/10.1002/jcp.21223)

Jackson SP \& Bartek J 2009 The DNA-damage response in human biology and disease. Nature 461 1071-1078. (https://doi.org/10.1038/ nature08467)

Jeschke J, Bizet M, Desmedt C, Calonne E, Dedeurwaerder S, Garaud S, Koch A, Larsimont D, Salgado R, Van den Eynden G, et al. 2017 DNA methylation-based immune response signature improves patient diagnosis in multiple cancers. Journal of Clinical Investigation 127 3090-3102. (https://doi.org/10.1172/JCI91095)

Kalluri R \& Weinberg RA 2009 The basics of epithelial-mesenchymal transition. Journal of Clinical Investigation 119 1420-1428. (https:// doi.org/10.1172/JCI39104)

Kastan MB 2008 DNA damage responses: mechanisms and roles in human disease: 2007 G.H.A. Clowes Memorial Award Lecture. Molecular Cancer Research 6 517-524. (https://doi.org/10.1158/15417786.MCR-08-0020)

Khaled YS, Ammori BJ \& Elkord E 2013 Myeloid-derived suppressor cells in cancer: recent progress and prospects. Immunology and Cell Biology 91 493-502. (https://doi.org/10.1038/icb.2013.29)

Khallouf H, Märten A, Serba S, Teichgräber V, Büchler MW, Jäger D \& Schmidt J 2012 5-Fluorouracil and interferon- $\alpha$ immunochemotherapy enhances immunogenicity of murine pancreatic cancer through upregulation of NKG2D ligands and MHC class I. Journal of Immunotherapy 35 245-253. (https://doi. org/10.1097/CJI.0b013e31824b3a76)

Kim JY, Lee E, Park K, Park WY, Jung HH, Ahn JS, Im YH \& Park YH 2017 Immune signature of metastatic breast cancer: identifying predictive markers of immunotherapy response. Oncotarget $\mathbf{8}$ 47400-47411. (https://doi.org/10.18632/oncotarget.23372)

Kininis M, Chen BS, Diehl AG, Isaacs GD, Zhang T, Siepel AC, Clark AG \& Kraus WL 2007 Genomic analyses of transcription factor binding, histone acetylation, and gene expression reveal mechanistically distinct classes of estrogen-regulated promoters. Molecular and Cellular Biology 27 5090-5104. (https://doi. org/10.1128/MCB.00083-07)

Kiraz, Y 2016 Major apoptotic mechanisms and genes involved in apoptosis. Tumor Biology 8471-8486. (https://doi.org/10.1007/s13277016-5035-9)

Kissick HT, Sanda MG, Dunn LK, Pellegrini KL, On ST, Noel JK \& Arredouani MS 2014 Androgens alter T-cell immunity by inhibiting T-helper 1 differentiation. PNAS 111 9887-9892. (https://doi. org/10.1073/pnas.1402468111)

Kochupurakkal BS, Wang ZC, Hua T, Culhane AC, Rodig SJ, RajkovicMolek K, Lazaro JB, Richardson AL, Biswas DK \& Iglehart JD 2015 RelA-induced interferon response negatively regulates proliferation. PLOS ONE 10 e0140243. (https://doi.org/10.1371/journal. pone.0140243)

Koh YT, Gray A, Higgins SA, Hubby B \& Kast WM 2009 Androgen ablation augments prostate cancer vaccine immunogenicity only when applied after immunization. Prostate 69 571-584. (https://doi. org/10.1002/pros.20906)

Kondo Y, Kanzawa T, Sawaya R \& Kondo S 2005 The role of autophagy in cancer development and response to therapy. Nature Reviews Cancer 5 726-734. (https://doi.org/10.1038/nrc1692)

Köstler WJ, Brodowicz T, Hejna M, Wiltschke C \& Zielinski CC 2000 Detection of minimal residual disease in patients with cancer: a review of techniques, clinical implications, and emerging therapeutic consequences. Cancer Detection and Prevention 24 376-403.

Koval A, Ahmed K \& Katanaev VL 2016 Inhibition of Wnt signalling and breast tumour growth by the multi-purpose drug suramin through suppression of heterotrimeric G proteins and Wnt endocytosis. Biochemical Journal 473 371-381. (https://doi. org/10.1042/BJ20150913)

Kryczek I, Banerjee M, Cheng P, Vatan L, Szeliga W, Wei S, Huang E, Finlayson E, Simeone D, Welling TH, et al. 2009 Phenotype, distribution, generation, and functional and clinical relevance of Th17 cells in the human tumor environments. Blood $\mathbf{1 1 4}$ 1141-1149. (https://doi.org/10.1182/blood-2009-03-208249)

Le Romancer M, Poulard C, Cohen P, Sentis S, Renoir JM \& Corbo L 2011 Cracking the estrogen receptor's posttranslational code in breast tumors. Endocrine Reviews 32 597-622. (https://doi. org/10.1210/er.2010-0016)
(C) 2018 Society for Endocrinology Published by Bioscientifica Ltd. Printed in Great Britain 
Leignadier J, Dalenc F, Poirot M \& Silvente-Poirot S 2017 Improving the efficacy of hormone therapy in breast cancer: the role of cholesterol metabolism in SERM-mediated autophagy, cell differentiation and death. Biochemical Pharmacology 144 18-28. (https://doi. org/10.1016/j.bcp.2017.06.120)

Levy E, Marty R, Gárate Calderón V, Woo B, Dow M, Armisen R, Carter H \& Harismendy O 2016 Immune DNA signature of T-cell infiltration in breast tumor exomes. Scientific Reports 630064. (https://doi.org/10.1038/srep30064)

Li X, Wu Q, Xie Y, Ding Y, Du WW, Sdiri M \& Yang BB 2015 Ergosterol purified from medicinal mushroom Amauroderma rude inhibits cancer growth in vitro and in vivo by up-regulating multiple tumor suppressors. Oncotarget 6 17832-17846. (https://doi.org/10.18632/ oncotarget.4026)

Li F, Zhao Y, Wei L, Li S \& Liu J 2018 Tumor-infiltrating Treg, MDSC, and IDO expression associated with outcomes of neoadjuvant chemotherapy of breast cancer. Cancer Biology and Therapy 695-705. (https://doi.org/10.1080/15384047.2018.1450116)

Lim SO, Li CW, Xia W, Lee HH, Chang SS, Shen J, Hsu JL, Raftery D, Djukovic D, Gu H, et al. 2016 EGFR signaling enhances aerobic glycolysis in triple-negative breast cancer cells to promote tumor growth and immune escape. Cancer Research 76 1284-1296. (https:// doi.org/10.1158/0008-5472.CAN-15-2478)

Lin CY, Vega VB, Thomsen JS, Zhang T, Kong SL, Xie M, Chiu KP, Lipovich L, Barnett DH, Stossi F, et al. 2007 Whole-genome cartography of estrogen receptor alpha binding sites. PLoS Genetics $\mathbf{3}$ e87. (https://doi.org/10.1371/journal.pgen.0030087)

Lin Y, Kuang W, Wu B, Xie C, Liu C \& Tu Z 2017 IL-12 induces autophagy in human breast cancer cells through AMPK and the PI3K/Akt pathway. Molecular Medicine Reports 16 4113-4118. (https:// doi.org/10.3892/mmr.2017.7114)

Ling A, Löfgren-Burström A, Larsson P, Li X, Wikberg ML, Öberg Å, Stenling R, Edin S \& Palmqvist R 2017 TAP1 down-regulation elicits immune escape and poor prognosis in colorectal cancer. Oncoimmunology 6 e1356143. (https://doi.org/10.1080/21624 02X.2017.1356143)

Lippman SM, Kavanagh JJ, Paredes-Espinoza M, Delgadillo-Madrueño F, Paredes-Casillas P, Hong WK, Holdener E \& Krakoff IH 1992 13-cisretinoic acid plus interferon alpha-2a: highly active systemic therapy for squamous cell carcinoma of the cervix. Journal of the National Cancer Institute 84 241-245. (https://doi.org/10.1093/ jnci/84.4.241)

Liu JC, Voisin V, Bader GD, Deng T, Pusztai L, Symmans WF, Esteva FJ, Egan SE \& Zacksenhaus E 2012 Seventeen-gene signature from enriched Her2/Neu mammary tumor-initiating cells predicts clinical outcome for human HER2+:Er $\alpha$ - breast cancer. PNAS 109 5832-5837. (https://doi.org/10.1073/pnas.1201105109)

Liu R, Liu C, Chen D, Yang WH, Liu X, Liu CG, Dugas CM, Tang F, Zheng P, Liu Y, et al. 2015 FOXP3 controls an miR-146/NF-кB negative feedback loop that inhibits apoptosis in breast cancer cells. Cancer Research 75 1703-1713. (https://doi.org/10.1158/0008-5472. CAN-14-2108)

Liu W, Zhou JG, Sun Y, Zhang L \& Xing BC 2016 The role of neoadjuvant chemotherapy for resectable colorectal liver metastases: a systematic review and meta-analysis. Oncotarget 7 37277-37287. (https://doi.org/10.18632/oncotarget.13871)

Liu JC, Zacksenhouse M, Eisen A, Nofech-Mozes S \& Zacksenhaus E 2017 Identification of cell proliferation, immune response and cell migration as critical pathways in a prognostic signature for HER2+:Ero- breast cancer. PLOS ONE 12 e0179223. (https://doi. org/10.1371/journal.pone.0179223)

Loi S, Dushyanthen S, Beavis PA, Salgado R, Denkert C, Savas P, Combs S, Rimm DL, Giltnane JM, Estrada MV, et al. 2016 RAS/MAPK activation is associated with reduced tumor-infiltrating lymphocytes in triple-negative breast cancer: therapeutic cooperation between MEK and PD-1/PD-L1 immune checkpoint inhibitors. Clinical Cancer
Research 22 1499-1509. (https://doi.org/10.1158/1078-0432.CCR-151125)

Loumagne L, Baudhuin J, Favier B, Montespan F, Carosella ED \& RouasFreiss N 2014 In vivo evidence that secretion of HLA-G by immunogenic tumor cells allows their evasion from immunosurveillance. International Journal of Cancer 135 2107-2117. (https://doi.org/10.1002/ijc.28845)

Ma LI, Chang Y, Yu L, He W \& Liu Y 2015 Pro-apoptotic and antiproliferative effects of mitofusin-2 via PI3K/Akt signaling in breast cancer cells. Oncology Letters 10 3816-3822. (https://doi.org/10.3892/ ol.2015.3748)

Ma M, Huang W \& Kong D 2018 IL-17 inhibits the accumulation of myeloid-derived suppressor cells in breast cancer via activating STAT3. International Immunopharmacology 59 148-156. (https://doi. org/10.1016/j.intimp.2018.04.013)

Maeda T, Hiraki M, Jin C, Rajabi H, Tagde A, Alam M, Bouillez A, Hu X, Suzuki Y, Miyo M, et al. 2018 MUC1-C induces PD-L1 and immune evasion in triple-negative breast cancer. Cancer Research 78 205-215. (https://doi.org/10.1158/0008-5472.CAN-17-1636)

Maj T, Wang W, Crespo J, Zhang H, Wang W, Wei S, Zhao L, Vatan L, Shao I, Szeliga W, et al. 2017 Oxidative stress controls regulatory T cell apoptosis and suppressor activity and PD-L1-blockade resistance in tumor. Nature Immunology 18 1332-1341. (https://doi. org/10.1038/ni.3868)

Mantovani A, Schioppa T, Porta C, Allavena P \& Sica A 2006 Role of tumor-associated macrophages in tumor progression and invasion. Cancer and Metastasis Reviews 25 315-322. (https://doi.org/10.1007/ s10555-006-9001-7)

Marinković M, Šprung M, Buljubašić M \& Novak I 2018 Autophagy modulation in cancer: current knowledge on action and therapy. Oxidative Medicine and Cellular Longevity 2018 8023821. (https://doi. org/10.1155/2018/8023821)

Markosyan N, Chen EP, Evans RA, Ndong V, Vonderheide RH \& Smyth EM 2013 Mammary carcinoma cell derived cyclooxygenase 2 suppresses tumor immune surveillance by enhancing intratumoral immune checkpoint activity. Breast Cancer Research 15 R75. (https:// doi.org/10.1186/bcr3469)

Martinez VG, O'Neill S, Salimu J, Breslin S, Clayton A, Crown J \& O'Driscoll L 2017 Resistance to HER2-targeted anti-cancer drugs is associated with immune evasion in cancer cells and their derived extracellular vesicles. Oncoimmunology 6 e1362530. (https://doi.org/1 $0.1080 / 2162402 X .2017 .1362530)$

Martínez-Canales S, Cifuentes F, López De Rodas Gregorio M, SerranoOviedo L, Galán-Moya EM, Amir E, Pandiella A, Győrffy B \& Ocaña A 2017 Transcriptomic immunologic signature associated with favorable clinical outcome in basal-like breast tumors. PLoS ONE 12 e0175128. (https://doi.org/10.1371/journal.pone.0175128)

McGranahan N, Rosenthal R, Hiley CT, Rowan AJ, Watkins TBK, Wilson GA, Birkbak NJ, Veeriah S, Van Loo P, Herrero J, et al. 2017 Allele-specific HLA loss and immune escape in lung cancer evolution. Cell 171 1259.e11-1271.e11. (https://doi.org/10.1016/j. cell.2017.10.001)

Medici D, Shore EM, Lounev VY, Kaplan FS, Kalluri R \& Olsen BR 2010 Conversion of vascular endothelial cells into multipotent stem-like cells. Nature Medicine 16 1400-1406. (https://doi.org/10.1038/ $\mathrm{nm} .2252)$

Migali C, Milano M, Trapani D, Criscitiello C, Esposito A, Locatelli M, Minchella I \& Curigliano G 2016 Strategies to modulate the immune system in breast cancer: checkpoint inhibitors and beyond. Therapeutic Advances in Medical Oncology 8 360-374. (https://doi. org/10.1177/1758834016658423)

Mihira H, Suzuki HI, Akatsu Y, Yoshimatsu Y, Igarashi T, Miyazono K \& Watabe T 2012 TGF- $\beta$-induced mesenchymal transition of MS-1 endothelial cells requires Smad-dependent cooperative activation of Rho signals and MRTF-A. Journal of Biochemistry 151 145-156. (https://doi.org/10.1093/jb/mvr121)
(2) 2018 Society for Endocrinology Published by Bioscientifica Ltd. Printed in Great Britain 
Mitry E, Fields AL, Bleiberg H, Labianca R, Portier G, Tu D, Nitti D, Torri V, Elias D, O'Callaghan C, et al. 2008 Adjuvant chemotherapy after potentially curative resection of metastases from colorectal cancer: a pooled analysis of two randomized trials. Journal of Clinical Oncology 26 4906-4911. (https://doi.org/10.1200/JCO.2008.17.3781)

Moon RC, McCormick DL \& Mehta RG 1983 Inhibition of carcinogenesis by retinoids. Cancer Research 43 (Supplement 5) 2469s-2475s.

Murphy K \& Weaver C 2016 Janeway's Immunobiology, 9th ed. New York, NY, USA: Garland Science, Taylor and Francis Group, LLC.

Muss HB, Caponera M, Zecan PG, Jackson DV Jr, Stuart JJ \& Richards F 1985 Recombinant gamma interferon in advanced breast cancer: a phase II trial. Investigational New Drugs 4 377-381.

Nicolini A \& Carpi A 2005 Beta-interferon and interleukin-2 prolong more than three times the survival of 26 consecutive endocrine dependent breast cancer patients with distant metastases: an exploratory trial. Biomedicine and Pharmacotherapy 59 253-263. (https://doi.org/10.1016/j.biopha.2004.05.019)

Nicolini A \& Carpi A 2009 Immune manipulation of advanced breast cancer: an interpretative model of the relationship between immune system and tumor cell biology. Medicinal Research Reviews 29 436-471. (https://doi.org/10.1002/med.20143)

Nicolini A, Carpi A, Ferrari P, Sagripanti A \& Anselmi L 1998 A multistep therapy with subcutaneous low dose recombinant interleukin-2, 5 -fluorouracil and leucovorin prolongs the response of metastatic colorectal cancer patients: a pilot study. Biomedicine and Pharmacotherapy 52 311-316. (https://doi.org/10.1016/S0753$3322(98) 80027-9)$

Nicolini A, Carpi A \& Rossi G 2005 An immunotherapy schedule in endocrine-dependent metastatic breast cancer: correlation between clinical course and immunologic parameters. Journal of Immunotherapy 28 276-279. (https://doi.org/10.1097/01. cji.0000156827.67572.53)

Nicolini A, Carpi A \& Rossi G 2006 Cytokines in breast cancer. Cytokine and Growth Factor Reviews 17 325-337. (https://doi.org/10.1016/j. cytogfr.2006.07.002)

Nicolini A, Carpi A \& Rossi G 2007 Relationship of cellular immunity, cytokines and CRP with clinical course in breast cancer patients with endocrine-dependent distant metastases treated with immunotherapy. Cancer Letters 251 330-338. (https://doi. org/10.1016/j.canlet.2006.12.002)

Nicolini A, Carpi A, Ferrari P \& Rossi G 2008 Immunotherapy prolongs the serum CEA-TPA-CA15.3 lead time at the metastatic progression in endocrine-dependent breast cancer patients: a retrospective longitudinal study. Cancer Letters 263 122-129. (https://doi. org/10.1016/j.canlet.2007.12.020)

Nicolini A, Conte M, Rossi G, Ferrari P, Carpi A \& Miccoli P 2010 A new pharmacological approach to gastrointestinal cancer at high risk of relapse based on maintenance of the cytostatic effect. Tumor Biology 31 523-532. (https://doi.org/10.1007/s13277-010-0065-1)

Nicolini A, Rossi G, Ferrari P \& Carpi A 2014a Clinical and laboratory patterns during immune stimulation in hormone responsive metastatic breast cancer. Biomedicine and Pharmacotherapy 68 171-178. (https://doi.org/10.1016/j.biopha.2013.11.005)

Nicolini A, Ferrari P, Biava PM \& Carpi A 2014b Changing the endocrine dependence of breast cancer: data and hypotheses. Current Medicinal Chemistry 21 1093-1106. (https://doi.org/10.2174/092986732166613 1201141741)

Nicolini A, Ferrari P, Kotlarova L, Rossi G \& Biava PM 2015 The PI3KAKt-mTOR pathway and new tools to prevent acquired hormone resistance in breast cancer. Current Pharmaceutical Biotechnology 16 804-815. (https://doi.org/10.2174/138920101609150715141545)

Nicolini A, Carpi A, Ferrari P, Biava PM \& Rossi G 2016 Immunotherapy and hormone-therapy in metastatic breast cancer: a review and an update. Current Drug Targets 17 1127-1139. (https://doi.org/10.2174/ 1389450117666160201114752)
Nicolini A, Barak V, Biava P, Ferrari P, Rossi G \& Carpi A 2018 Use of immunotherapy to treat metastatic breast cancer. Current Medicinal Chemistry [epub]. (https://doi.org/10.2174/0929867325666180209124 052)

Ning Y, Riggins RB, Mulla JE, Chung H, Zwart A \& Clarke R 2010 IFNgamma restores breast cancer sensitivity to fulvestrant by regulating STAT1, IFN regulatory factor 1, NF-kappaB, BCL2 family members, and signaling to caspase-dependent apoptosis. Molecular Cancer Therapeutics 9 1274-1285. (https://doi.org/10.1158/15357163.MCT-09-1169)

Olesch C, Sha W, Angioni C, Sha LK, Açaf E, Patrignani P, Jakobsson PJ, Radeke HH, Grösch S, Geisslinger G, et al. 2015 MPGES-1-derived PGE2 suppresses CD80 expression on tumor-associated phagocytes to inhibit anti-tumor immune responses in breast cancer. Oncotarget 6 10284-10296. (https://doi.org/10.18632/oncotarget.3581)

Osborne CK 1994 Interactions of tamoxifen with cytotoxic chemotherapy for breast cancer. In Long-Term Tamoxifen Treatment for Breast Cancer, pp 181-196. Ed VC Jordan. Madison, WI, USA: The University of Wisconsin Press.

Paik S, Shak S, Tang G, Kim C, Baker J, Cronin M, Baehner FL, Walker MG, Watson D, Park T, et al. 2004 A multigene assay to predict recurrence of tamoxifen-treated, node-negative breast cancer. New England Journal of Medicine 351 2817-2826. (https://doi. org/10.1056/NEJMoa041588)

Pantel K, Schlimok G, Braun S, Kutter D, Lindemann F, Schaller G, Funke I, Izbicki JR \& Riethmüller G 1993 Differential expression of proliferation-associated molecules in individual micrometastatic carcinoma cells. Journal of the National Cancer Institute 85 1419-1424. (https://doi.org/10.1093/jnci/85.17.1419)

Perez EA, Thompson EA, Ballman KV, Anderson SK, Asmann YW, Kalari KR, Eckel-Passow JE, Dueck AC, Tenner KS, Jen J, et al. 2015 Genomic analysis reveals that immune function genes are strongly linked to clinical outcome in the North Central Cancer Treatment Group n9831 Adjuvant Trastuzumab Trial. Journal of Clinical Oncology 33 701-708. (https://doi.org/10.1200/JCO.2014.57.6298)

Perou CM, Sørlie T, Eisen MB, van de Rijn M, Jeffrey SS, Rees CA, Pollack JR, Ross DT, Johnsen H, Akslen LA, et al. 2000 Molecular portraits of human breast tumours. Nature 406 747-752. (https://doi. org/10.1038/35021093)

Portier G, Elias D, Bouche O, Rougier P, Bosset JF, Saric J, Belghiti J, Piedbois P, Guimbaud R, Nordlinger B, et al. 2006 Multicenter randomized trial of adjuvant fluorouracil and folinic acid compared with surgery alone after resection of colorectal liver metastases: FFCD ACHBTH AURC 9002 trial. Journal of Clinical Oncology 24 4976-4982. (https://doi.org/10.1200/JCO.2006.06.8353)

Potenta S, Zeisberg E \& Kalluri R 2008 The role of endothelial-tomesenchymal transition in cancer progression. British Journal of Cancer 99 1375-1379. (https://doi.org/10.1038/sj.bjc.6604662)

Prabhala RH, Garewal HS, Hicks MJ, Sampliner RE \& Watson RR 1991 The effects of 13-cis-retinoic acid and beta-carotene on cellular immunity in humans. Cancer 67 1556-1560. (https://doi. org/10.1002/1097-0142(19910315)67:6<1556::AIDCNCR2820670616>3.0.CO;2-O)

Recchia F, Frati L, Rea S, Torchio P \& Sica G 1998 Minimal residual disease in metastatic breast cancer: treatment with IFN-beta, retinoids, and tamoxifen. Journal of Interferon and Cytokine Research 18 41-47. (https://doi.org/10.1089/jir.1998.18.41)

Recchia F, Saggio G, Cesta A, Candeloro G, Nuzzo A, Lombardo M, Carta G \& Rea S 2005 Interleukin-2 and 13-cis retinoic acid as maintenance therapy in advanced ovarian cancer. International Journal of Oncology 27 1039-1046.

Recchia F, Saggio G, Nuzzo A, Biondi E, Di Blasio A, Cesta A, Candeloro G, Alesse E \& Rea S 2006 Multicenter phase 2 study of interleukin-2 and 13-cis retinoic acid as maintenance therapy in advanced non-small-cell lung cancer. Journal of Immunotherapy $\mathbf{2 9}$ 87-94. (https://doi.org/10.1097/01.cji.0000186244.85058.1b) 
Recchia F, Saggio G, Cesta A, Candeloro G, Di Blasio A, Amiconi G, Lombardo M, Nuzzo A, Lalli A, Alesse A, et al. 2007 Phase II study of interleukin-2 and 13-cis-retinoic acid as maintenance therapy in metastatic colorectal cancer. Cancer Immunology, Immunotherapy 56 699-708 (https://doi.org/10.1007/s00262-006-0224-9)

Recchia F, Sica G, Candeloro G, Necozione S, Bisegna R, Bratta M \& Rea S 2008 Maintenance immunotherapy in metastatic breast cancer. Oncology Reports 20 1173-1179.

Rodenhiser DI, Andrews J, Kennette W, Sadikovic B, Mendlowitz A, Tuck AB \& Chambers AF 2008 Epigenetic mapping and functional analysis in a breast cancer metastasis model using whole-genome promoter tiling microarrays. Breast Cancer Research 10 R62. (https:// doi.org/10.1186/bcr2121)

Rodríguez JA 2017 HLA-mediated tumor escape mechanisms that may impair immunotherapy clinical outcomes via T-cell activation. Oncology Letters 14 4415-4427. (https://doi.org/10.3892/ ol.2017.6784)

Rohatgi RA, Janusis J, Leonard D, Bellvé KD, Fogarty KE, Baehrecke EH, Corvera S \& Shaw LM 2015 Beclin 1 regulates growth factor receptor signaling in breast cancer. Oncogene 34 5352-5362. (https://doi. org/10.1038/onc.2014.454)

Roskoski R Jr 2014 The ErbB/HER family of protein-tyrosine kinases and cancer. Pharmacological Research 79 34-74. (https://doi.org/10.1016/j. phrs.2013.11.002)

Rothenberger NJ, Somasundaram A \& Stabile LP 2018 The role of the estrogen pathway in the tumor microenvironment. International Journal of Molecular Sciences 19 E611. (https://doi.org/10.3390/ ijms19020611)

Rouschop KM, van den Beucken T, Dubois L, Niessen H, Bussink J, Savelkouls K, Keulers T, Mujcic H, Landuyt W, Voncken JW, et al. 2010 The unfolded protein response protects human tumor cells during hypoxia through regulation of the autophagy genes MAP1LC3B and ATG5. Journal of Clinical Investigation 120 127-141. (https://doi.org/10.1172/JCI40027)

Roved J, Westerdahl H \& Hasselquist D 2017 Sex differences in immune responses: hormonal effects, antagonistic selection, and evolutionary consequences. Hormones and Behavior 88 95-105. (https://doi. org/10.1016/j.yhbeh.2016.11.017)

Saqcena M, Patel D, Menon D, Mukhopadhyay S \& Foster DA 2015 Apoptotic effects of high-dose rapamycin occur in S-phase of the cell cycle. Cell Cycle 14 2285-2292. (https://doi.org/10.1080/15384101.20 15.1046653)

Savci-Heijink CD, Halfwerk H, Hooijer GK, Horlings HM, Wesseling J \& van de Vijver MJ 2015 Retrospective analysis of metastatic behaviour of breast cancer subtypes. Breast Cancer Research and Treatment $\mathbf{1 5 0}$ 547-557. (https://doi.org/10.1007/s10549-015-3352-0)

Sayeed A, Luciani-Torres G, Meng Z, Bennington JL, Moore DH \& Dairkee SH 2013 Aberrant regulation of the BST2 (Tetherin) promoter enhances cell proliferation and apoptosis evasion in high grade breast cancer cells. PLOS ONE 8 e67191. (https://doi. org/10.1371/journal.pone.0067191)

Scheele J, Stangl R \& Altendorf-Hofmann A 1990 Hepatic metastases from colorectal carcinoma: impact of surgical resection on the natural history. British Journal of Surgery 77 1241-1246. (https://doi. org/10.1002/bjs.1800771115)

Schwartz JL, Shajahan AN \& Clarke R 2011 The role of interferon regulatory factor-1 (IRF1) in overcoming antiestrogen resistance in the treatment of breast cancer. International Journal of Breast Cancer 2011 912102. (https://doi.org/10.4061/2011/912102)

Schwartz-Roberts JL, Cook KL, Chen C, Shajahan-Haq AN, Axelrod M, Wärri A, Riggins RB, Jin L, Haddad BR, Kallakury BV, et al. 2015 Interferon regulatory factor-1 signaling regulates the switch between autophagy and apoptosis to determine breast cancer cell fate. Cancer Research 75 1046-1055. (https://doi.org/10.1158/0008-5472.CAN-141851)
Seo HS, Woo JK, Shin YC \& Ko SG 2015 Identification of biomarkers regulated by rexinoids (LGD1069, LG100268 and Ro25-7386) in human breast cells using Affymetrix microarray. Molecular Medicine Reports 12 800-818. (https://doi.org/10.3892/mmr.2015.3480)

Setrerrahmane S, Xu H 2017 Tumor-related interleukins: old validated targets for new anti-cancer drug development. Molecular Cancer 16 153. (https://doi.org/10.1186/s12943-017-0721-9)

Sevko A, Kremer V, Falk C, Umansky L, Shurin MR, Shurin GV \& Umansky V 2012 Application of paclitaxel in low non-cytotoxic doses supports vaccination with melanoma antigens in normal mice. Journal of Immunotoxicology 9 275-281. (https://doi.org/10.3109/1547 691X.2012.655343)

Sherwin SA, Mayer D, Ochs JJ, Abrams PG, Knost JA, Foon KA, Fein S \& Oldham RK 1983 Recombinant leukocyte A interferon in advanced breast cancer. Results of a phase II efficacy trial. Annals of Internal Medicine 98 598-602. (https://doi.org/10.7326/0003-4819-98-5-598)

Shrestha A, Nepal S, Kim MJ, Chang JH, Kim SH, Jeong GS, Jeong CH, Park GH, Jung S, Lim J et al. 2016 Critical role of AMPK/FoxO3A axis in globular adiponectin-induced cell cycle arrest and apoptosis in cancer cells. Journal of Cellular Physiology 231 357-369. (https://doi. org/10.1002/jcp.25080)

Shurin GV, Tourkova IL, Kaneno R \& Shurin MR 2009 Chemotherapeutic agents in noncytotoxic concentrations increase antigen presentation by dendritic cells via an IL-12-dependent mechanism. Journal of Immunology 183 137-144. (https://doi. org/10.4049/jimmunol.0900734)

Siegel RL, Miller KD \& Jemal A 2016 Cancer statistics, 2016. CA: A Cancer Journal for Clinicians 66 7-30. (https://doi.org/10.3322/ caac. 21332)

Smithson LJ, Anastasaki C, Chen R, Toonen JA, Williams SB \& Gutmann DH 2016 Contextual signaling in cancer. Seminars in Cell and Developmental Biology 58 118-126. (https://doi.org/10.1016/j. semcdb.2016.06.002)

Song H, Wu C, Wei C, Li D, Hua K, Song J, Xu H, Chen L \& Fang L 2015 Silencing of DUSP6 gene by RNAi-mediation inhibits proliferation and growth in MDA-MB-231 breast cancer cells: an in vitro study. International Journal of Clinical and Experimental Medicine 8 10481-10490.

SPN, Darvin P, Yoo YB, Joung YH, Kang DY, Kim DN, Hwang TS, Kim SY, Kim WS, Lee HK, et al. 2015 The combination of methylsulfonylmethane and tamoxifen inhibits the Jak2/STAT5b pathway and synergistically inhibits tumor growth and metastasis in ER-positive breast cancer xenografts. BMC Cancer 15 474. (https:// doi.org/10.1186/s12885-015-1445-0)

Sporn MB \& Roberts AB 1983 Role of retinoids in differentiation and carcinogenesis. Cancer Research 43 3034-3040.

Steggerda SM, Bennett MK, Chen J, Emberley E, Huang T, Janes JR, Li W, MacKinnon AL, Makkouk A, Marguier G, et al. 2017 Inhibition of arginase by CB-1158 blocks myeloid cell-mediated immune suppression in the tumor microenvironment. Journal for ImmunoTherapy of Cancer 5 101. (https://doi.org/10.1186/s40425-0170308-4)

Stephens PJ, Tarpey PS, Davies H, Van Loo P, Greenman C, Wedge DC, Nik-Zainal S, Martin S, Varela I, Bignell GR, et al. 2012 The landscape of cancer genes and mutational processes in breast cancer. Nature 486 400-404. (https://doi.org/10.1038/nature11017)

Tao S, He H, Chen Q \& Yue W 2014 GPER mediated estradiol reduces miR-148a to promote HLA-G expression in breast cancer. Biochemical and Biophysical Research Communications 451 74-78. (https://doi. org/10.1016/j.bbrc.2014.07.073)

Tavera-Mendoza LE, Westerling T, Libby E, Marusyk A, Cato L, Cassani R, Cameron LA, Ficarro SB, Marto JA, Klawitter J, et al. 2017 Vitamin D receptor regulates autophagy in the normal mammary gland and in luminal breast cancer cells. PNAS 114 E2186-E2194. (https://doi.org/10.1073/pnas.1615015114)
2018 Society for Endocrinology Published by Bioscientifica Ltd. Printed in Great Britain 
The Nordic Myeloma Study Group 1996 Interferon-alpha 2b added to melphalan-prednisone for initial and maintenance therapy in multiple myeloma. A randomized, controlled trial. Annals of Internal Medicine 124 212-222.

Tosolini M, Kirilovsky A, Mlecnik B, Fredriksen T, Mauger S, Bindea G, Berger A, Bruneval P, Fridman WH, Pagès F, et al. 2011 Clinical impact of different classes of infiltrating $\mathrm{T}$ cytotoxic and helper cells (Th1, th2, treg, th17) in patients with colorectal cancer. Cancer Research 71 1263-1271. (https://doi.org/10.1158/0008-5472.CAN-102907)

Toss A, Grandi G, Cagnacci A, Marcheselli L, Pavesi S, De Matteis E, Razzaboni E, Tomasello C, Cascinu S \& Cortesi L 2017 The impact of reproductive life on breast cancer risk in women with family history or BRCA mutation. Oncotarget 8 9144-9154. (https://doi. org/10.18632/oncotarget.13423)

Tyagi AM, Srivastava K, Mansoori MN, Trivedi R, Chattopadhyay N \& Singh D 2012 Estrogen deficiency induces the differentiation of IL-17 secreting Th17 cells: a new candidate in the pathogenesis of osteoporosis. PLoS ONE 7 e44552. (https://doi.org/10.1371/journal pone.0044552)

Ueno T, Saji S, Sugimoto M, Masuda N, Kuroi K, Sato N, Takei H, Yamamoto Y, Ohno S, Yamashita H, et al. 2016 Clinical significance of the expression of autophagy-associated marker, beclin 1, in breast cancer patients who received neoadjuvant endocrine therapy. BMC Cancer 16 230. (https://doi.org/10.1186/s12885-016-2270-9)

Uray IP \& Brown PH 2011 Chemoprevention of hormone receptornegative breast cancer: new approaches needed. Recent Results in Cancer Research 188 147-162. (https://doi.org/10.1007/978-3-64210858-7_13)

van de Vijver MJ, He YD, van't Veer LJ, Dai H, Hart AA, Voskuil DW, Schreiber GJ, Peterse JL, Roberts C, Marton MJ, et al. 2002 A geneexpression signature as a predictor of survival in breast cancer. New England Journal of Medicine 347 1999-2009. (https://doi.org/10.1056/ NEJMoa021967)

van Geldermalsen M, Wang Q, Nagarajah R, Marshall AD, Thoeng A, Gao D, Ritchie W, Feng Y, Bailey CG, Deng N, et al. 2016 ASCT2/ SLC1A5 controls glutamine uptake and tumour growth in triplenegative basal-like breast cancer. Oncogene 35 3201-3208. (https:// doi.org/10.1038/onc.2015.381)

Varadan V, Gilmore H, Miskimen KL, Tuck D, Parsai S, Awadallah A, Krop IE, Winer EP, Bossuyt V, Somlo G, et al. 2016 Immune signatures following single dose trastuzumab predict pathologic response to preoperativetrastuzumab and chemotherapy in HER2positive early breast cancer. Clinical Cancer Research 22 3249-3259. (https://doi.org/10.1158/1078-0432.CCR-15-2021)

Vasaturo A, Verdoes M, de Vries J, Torensma R \& Figdor CG 2015 Restoring immunosurveillance by dendritic cell vaccines and manipulation of the tumor microenvironment. Immunobiology 220 243-248. (https://doi.org/10.1016/j.imbio.2014.11.007)

Verigos J \& Magklara A 2015 Revealing the complexity of breast cancer by next generation sequencing. Cancers 7 2183-2200. (https://doi. org/10.3390/cancers7040885)

Virtanen SS, Kukkonen-Macchi A, Vainio M, Elima K, Härkönen PL, Jalkanen S \& Yegutkin GG 2014 Adenosine inhibits tumor cell invasion via receptor-independent mechanisms. Molecular Cancer Research 12 1863-1874. (https://doi.org/10.1158/1541-7786.MCR-140302-T)

Wang Y \& Navin NE 2015 Advances and applications of single-cell sequencing technologies. Molecular Cell 58 598-609. (https://doi. org/10.1016/j.molcel.2015.05.005)

Wang C, Dehghani B, Li Y, Kaler LJ, Vandenbark AA \& Offner H 2009 Oestrogen modulates experimental autoimmune encephalomyelitis and interleukin-17 production via programmed death 1. Immunology 126 329-335. (https://doi.org/10.1111/j.1365-2567.2008.03051.x)

Wang Y, Waters J, Leung ML, Unruh A, Roh W, Shi X, Chen K, Scheet P, Vattathil S, Liang H, et al. 2014 Clonal evolution in breast cancer revealed by single nucleus genome sequencing. Nature 512 155-160. (https://doi.org/10.1038/nature13600)

Wang C, Wang C, Wei Z, Li Y, Wang W, Li X, Zhao J, Zhou X, Qu X \& Xiang F 2015a Suppression of motor protein KIF3C expression inhibits tumor growth and metastasis in breast cancer by inhibiting TGF- $\beta$ signaling. Cancer Letters 368 105-114. (https://doi. org/10.1016/j.canlet.2015.07.037)

Wang J, Song YX, Ma B, Wang JJ, Sun JX, Chen XW, Zhao JH, Yang YC \& Wang ZN $2015 b$ Regulatory roles of non-coding RNAs in colorectal cancer. International Journal of Molecular Sciences 16 19886-19919. (https://doi.org/10.3390/ijms160819886)

Wang YL, Overstreet AM, Chen MS, Wang J, Zhao HJ, Ho PC, Smith M \& Wang SC 2015c Combined inhibition of EGFR and c-ABL suppresses the growth of triple-negative breast cancer growth through inhibition of HOTAIR. Oncotarget 6 11150-11161. (https:// doi.org/10.18632/oncotarget.3441)

Wang S, Wang K, Wang H, Han J \& Sun H 2017 Autophagy is essential for flavopiridol-induced cytotoxicity against MCF-7 breast cancer cells. Molecular Medicine Reports 16 9715-9720. (https://doi. org/10.3892/mmr.2017.7815)

Weber F, Shen L, Fukino K, Patocs A, Mutter GL, Caldes T \& Eng C 2006 Total-genome analysis of BRCA1/2-related invasive carcinomas of the breast identifies tumor stroma as potential landscaper for neoplastic initiation. American Journal of Human Genetics 78 961-972. (https:// doi.org/10.1086/504090)

Welboren WJ, van Driel MA, Janssen-Megens EM, van Heeringen SJ, Sweep FC, Span PN \& Stunnenberg HG 2009 ChIP-Seq of ERalpha and RNA polymerase II defines genes differentially responding to ligands. EMBO Journal 28 1418-1428. (https://doi.org/10.1038/ emboj.2009.88)

Wellbrock C \& Arozarena I 2016 The complexity of the ERK/MAP-kinase pathway and the treatment of melanoma skin cancer. Frontiers in Cell and Developmental Biology 4 33. (https://doi.org/10.3389/ fcell.2016.00033)

Welt A, Marschner N, Lerchenmueller C, Decker T, Steffens CC, Koehler A, Depenbusch R, Busies S \& Hegewisch-Becker S 2016 Capecitabine and bevacizumab with or without vinorelbine in firstline treatment of HER2/neu-negative metastatic or locally advanced breast cancer: final efficacy and safety data of the randomised, openlabel superiority phase 3 CARIN trial. Breast Cancer Research and Treatment 156 97-107. (https://doi.org/10.1007/s10549-016-3727-x)

Wolf DM, Gottardis MM \& Jordan VC 1994 Tamoxifen-resistant growth. In Long-Term Tamoxifen Treatment for Breast Cancer, pp 199-217. Ed VC Jordan. Madison, WI, USA: The University of Wisconsin Press.

Xu YM, Wang HJ, Chen F, Guo WH, Wang YY, Li HY, Tang JH, Ding Y, Shen YC, Li M, et al. 2015 HRD1 suppresses the growth and metastasis of breast cancer cells by promoting IGF-1R degradation. Oncotarget 6 42854-42867. (https://doi.org/10.18632/ oncotarget.5733)

Xu Z, Shen J, Wang MH, Yi T, Yu Y, Zhu Y, Chen B, Chen J, Li L, Li M, et al. 2016 Comprehensive molecular profiling of the B7 family of immune-regulatory ligands in breast cancer. Oncoimmunology 5 e1207841. (https://doi.org/10.1080/2162402X.2016.1207841)

Yachida S, Jones S, Bozic I, Antal T, Leary R, Fu B, Kamiyama M, Hruban RH, Eshleman JR, Nowak MA, et al. 2010 Distant metastasis occurs late during the genetic evolution of pancreatic cancer. Nature 467 1114-1117. (https://doi.org/10.1038/nature09515)

Yang L, Zheng A, Zhang X, Fang X, Sun W \& Chen Y 2017 Clear cell carcinoma of the uterine cervix: a clinical and pathological analysis of 47 patients without intrauterine diethylstilbestrol exposure. International Journal of Gynecological Cancer 27 1009-1014. (https:// doi.org/10.1097/IGC.0000000000000992

Yao G, Liang J, Han X \& Hou Y 2003 In vivo modulation of the circulating lymphocyte subsets and monocytes by androgen. International Immunopharmacology 3 1853-1860. (https://doi. org/10.1016/j.intimp.2003.09.002)
(2) 2018 Society for Endocrinology Published by Bioscientifica Ltd. Printed in Great Britain 
Yoshihama S, Roszik J, Downs I, Meissner TB, Vijayan S, Chapuy B, Sidiq T, Shipp MA, Lizee GA \& Kobayashi KS 2016 NLRC5/MHC class I transactivator is a target for immune evasion in cancer. PNAS 113 5999-6004. (https://doi.org/10.1073/pnas.1602069113)

You DJ, Mander S, Park CR, Koo O, Lee C, Oh SH, Ahn C, Seong JY \& Hwang JI 2016 NME1L negatively regulates IGF1-dependent proliferation of breast cancer cells. Journal of Cellular Biochemistry 117 1454-1463. (https://doi.org/10.1002/jcb.25441)

Zardavas D, Irrthum A, Swanton C \& Piccart M 2015 Clinical management of breast cancer heterogeneity. Nature Reviews Clinical Oncology 12 381-394. (https://doi.org/10.1038/nrclinonc.2015.73)

Zelenay S, van der Veen AG, Böttcher JP, Snelgrove KJ, Rogers N, Acton SE, Chakravarty P, Girotti MR, Marais R, Quezada SA, et al. 2015 Cyclooxygenase-dependent tumor growth through evasion of immunity. Cell 162 1257-1270. (https://doi.org/10.1016/j. cell.2015.08.015)

Zhang H, Lu H, Xiang L, Bullen JW, Zhang C, Samanta D, Gilkes DM, He J \& Semenza GL 2015a HIF-1 regulates CD47 expression in breast cancer cells to promote evasion of phagocytosis and maintenance of cancer stem cells. PNAS 112 E6215-E6223. (https://doi.org/10.1073/ pnas.1520032112)

Zhang M, Yan L \& Kim JA 2015 $b$ Modulating mammary tumor growth, metastasis and immunosuppression by siRNA-induced MIF reduction in tumor microenvironment. Cancer Gene Therapy 22 463-474. (https://doi.org/10.1038/cgt.2015.42)

Zhang YX, Yan L, Liu GY, Chen WJ, Gong WH \& Yu JM 2015c Inhibition of janus kinase 2 by compound AG490 suppresses the proliferation of MDA-MB-231 cells via up-regulating SARI (suppressor of AP-1, regulated by IFN). Iranian Journal of Basic Medical Sciences $\mathbf{1 8}$ 599-603.

Zhou X, Deng S, Liu H, Liu Y, Yang Z, Xing T, Jing B \& Zhang X 2015 Knockdown of ubiquitin protein ligase E3A affects proliferation and invasion and induces apoptosis of breast cancer cells through regulation of annexin A2. Molecular Medicine Reports 12 1107-1113. (https://doi.org/10.3892/mmr.2015.3549)

Zhou H, Zheng L, Lu K, Gao Y, Guo L, Xu W \& Wang X 2017a Downregulation of cohesin loading factor nipped-B-like protein (NIPBL) induces cell cycle arrest, apoptosis, and autophagy of breast cancer cell lines. Medical Science Monitor 23 4817-4825. (https://doi. org/10.12659/MSM.906583)

Zhou J, Hang D, Jiang Y, Chen J, Han J, Zhou W, Jin G, Ma H \& Dai J $2017 b$ Evaluation of genetic variants in autophagy pathway genes as prognostic biomarkers for breast cancer. Gene 627 549-555. (https:// doi.org/10.1016/j.gene.2017.06.053)

Zhou X, Yue GG, Chan AM, Tsui SK, Fung KP, Sun H, Pu J \& Lau CB 2017 c Eriocalyxin B, a novel autophagy inducer, exerts anti-tumor activity through the suppression of Akt/mTOR/p70S6K signaling pathway in breast cancer. Biochemical Pharmacology 142 58-70. (https://doi.org/10.1016/j.bcp.2017.06.133)

Zielinski C, Láng I, Inbar M, Kahán Z, Greil R, Beslija S, Stemmer SM, Zvirbule Z, Steger GG, Melichar B, et al. 2016 Bevacizumab plus paclitaxel versus bevacizumab plus capecitabine as first-line treatment for HER2-negative metastatic breast cancer (TURANDOT): primary endpoint results of a randomised, open-label, noninferiority, phase 3 trial. Lancet Oncology 17 1230-1239. (https://doi. org/10.1016/S1470-2045(16)30154-1)

Received in final form 14 June 2018

Accepted 3 July 2018

Accepted Preprint published online 4 July 2018
(C) 2018 Society for Endocrinology Published by Bioscientifica Ltd. Printed in Great Britain 